\title{
Hegel e o problema do Saber absoluto na Fenomenologia do Espírito: Ou, de como a consciência-de-si do Espírito se torna objeto de sua consciência?
}

\author{
Manuel Moreira da Silva
}

11 de agosto de 2008

\begin{abstract}
Resumo
Trata-se de uma consideração especulativa em torno da instauração do Saber absoluto; mais precisamente, da concepção hegeliana da mesma, apresentada no capítulo final da Phänomenologie des Geistes de 1807. Pretende-se pôr em evidência o caráter autoconstitutivo e autoregulativo dos princípios motores do Especulativo puro nos limites de sua instauração fenomenológica enquanto Saber absoluto, isto é, como pano de fundo - implícito - da mesma; ou ainda, de modo mais rigoroso, da determinação da estrutura imanente - lógico-efetiva - do Saber absoluto, aliás, do modo como a consciência-de-si do Espírito se torna objeto de sua consciência. Com o que, ao fim e ao cabo, poder-se atestar o fato mesmo da Consciência-de-si do Espírito tornar-se objeto de sua Consciência e a consistência de tal fato, isto é, da instauração do Saber absoluto.

Palavras-chave: Hegel, Fenomenologia do espírito, Saber absoluto, Especulativo puro.

ABSTRACT: This is a speculative consideration on the instauration of absolute knowing; more precisely, of the Hegelian conception of the same, presented in the final chapter of Phänomenologie des Geistes of 1807. It is intended to highlight the self-constitutive and self-regulative character of the engines principles of pure speculative in the limits of its phenomenological establishment while absolute knowing, that is, as a background - implicit - of the same, or, in a more rigorous mode, of the determination of the immanent structure - logical-effective - of the absolute knowing, in fact, of how the self-consciousness of the Spirit becomes the object of its consciousness. With that, in the end, be able to certify the fact that the self-consciousness of the Spirit become the object of its consciousness and the consistency of this fact, it is, of establishment of absolute knowing.
\end{abstract}

Keywords: Hegel, Phenomenology of the spirit, Absolute knowing, Pure speculative 


\section{Considerações preliminares:}

Trata-se de uma consideração especulativa em torno da instauração do Saber absoluto; mais precisamente, da concepção hegeliana da mesma, apresentada no capítulo final da Phänomenologie des Geistes de $1807^{1}$. Limitando-nos aos $\S \S$ 788-797 dessa obra, isto é, aos dez primeiros parágrafos do capítulo em questão, investigaremos em que medida o acesso ao Saber absoluto não apenas pressupõe a existência e o caráter operativo de determinados princípios motores fundantes de tal Saber -, mas também os exige como os elementos autoconstitutivos e autoregulativos primordiais da referida instauração e, por conseguinte, do desenvolvimento mesmo do Saber absoluto enquanto tal. De um lado, o caráter operativo dos princípios motores aludidos os apresenta como condição metodológico-especulativa, necessária e suficiente ou absoluta, da instauração e do desenvolvimento referido; de outro, seu caráter autoconstitutivo e autoregulativo os conforma como a estrutura metafísico-especulativa ou lógico-efetiva imanente não só da instauração e do desenvolvimento do Saber absoluto como Filosofia especulativa pura - mais precisamente da Lógica especulativa - mas sobretudo do próprio Especulativo puro que aí se instaura e se desenvolve em si e para si, em si e para si mesmo. Desse modo, antes de tudo, há sobretudo que se pôr em evidência o caráter autoconstitutivo e autoregulativo dos princípios motores do Especulativo puro, aqui, nos limites de sua instauração fenomenológica enquanto Saber absoluto, isto é, como pano de fundo - implícito - da mesma; ou ainda, de modo mais rigoroso, da determinação da estrutura lógico-efetiva do próprio Saber absoluto, aliás, do modo como a consciência-de-si do Espírito se torna objeto de sua consciência. Assim, na medida em que a instauração do Saber absoluto na Phänomenologie des Geistes não é nada mais que o estabelecimento do conceito da Ciência especulativa, nosso intento repousara numa abordagem do Saber absoluto segundo o que designamos os princípios motores da Lógica especulativa em geral e do Especulativo puro em especial ${ }^{2}$. Por isso, antes de prosseguir, precisemos o que aqui queremos dizer com os termos 'Especulativo puro' e 'Princípios motores'.

Por 'Especulativo puro' entendemos o Elemento especulativo ou o Racional positivo enquanto distinto e mesmo oposto ao Dialético, isto é, ao Racional negativo ${ }^{3}$. Assim, o Especulativo puro é o próprio Conceito especulativo na me-

\footnotetext{
${ }^{1}$ G. W. F. HEGEL, Phänomenologie des Geistes (1807), neu hrsg. von Hans-Friedrich Wessels u. Heirinch Clairmont. Mit e. Einleitung von Wolfgang Bonsiepen. Hamburg: Meiner, 1988, p. 516-531. Para facilitar a leitura dessa obra, além da paginação dessa edição original, lançaremos mão da numeração dos parágrafos utilizada na versão Meneses [Fenomenologia do Espírito, - 2. Ed. - São Paulo: Loyola, 2003]; assim, de ora avante, citaremos a referida obra pelas iniciais ' $\mathrm{PhG}$ ', seguida de ' $\S$ ' e do número dos respectivos parágrafos, e (entre parêntesis) do número da página correspondente na edição original utilizada. De onde, para o caso em questão: PhG, $\S \S 788-808$ (p. 516-531).

${ }^{2}$ Ver: SILVA, M. M. O problema da Fundação especulativa do Especulativo puro no Sistema de Hegel e a determinação especulativa dos Princípios motores da Lógica especulativa, in: Revista Eletrônica Estudos Hegelianos, Recife/PE, v. 02, n. 03, (2005): URL = $<$ http://www.hegelbrasil.org/rev03e.htm>. Acesso em janeiro de 2008.

${ }^{3}$ Ver, G. W. F. HEGEL, Vorlesunguen über Logik und Metaphysik (Heidelberg 1817). Mitgeschrieben von F. A. Good. Herausgegeben von Karen Gloy, unter Mitarbeit von Manuel
} 
dida em que este é o que é livre em si e para si ou, o que é o mesmo, o Espírito livre enquanto Espírito que se sabe a si mesmo como Espírito e que, portanto, na esfera do Saber absoluto, já se despojou daquelas aparências contingentes, às quais, em seu aparecer - como em sua aparição ou fenômeno -, o mesmo estava subordinado. De onde, por conseguinte, a sua necessária liberação, sobretudo da oposição do Ser-consciente em geral e seu objeto intencional enquanto algo dado na representação ou na consciência em geral ${ }^{4}$. Essa compreensão do Especulativo puro implica em que se reconheça uma esfera lógico-efetiva distinta da esfera fenomenológica - que se constitui como o plano da experiência do Serconsciente e, portanto, do aparecer do Espírito enquanto cindido dentro de si e da esfera meramente lógico-abstrata, seja ela geral, formal ou transcendental - que se constitui como o plano da própria cisão entre o formal e o material, a essência e o fenômeno, a priori e o a posteriori, o essencial e o inessencial, o necessário e o contingente, o interior e o exterior, o efetivo e o aparente, etc. -, uma esfera lógico-efetiva na qual e a partir da qual a essência não tenha mais que se reportar a um ser ou aparecer, mas possa determinar-se a si mesma dentro de si como Sujeito livre em si e para $\mathrm{si}^{5}$. Essa a esfera da essencialidade espiritual pura que se tornou autoconsciente e que, em assim se sabendo, põe e se dá - como suas - suas próprias determinações ${ }^{6}$; determinações estas que devem saber-se a si mesmas como essencialidades espirituais puras, essências ou conceitos conscientes que, enquanto livres, se sabem não como o que pensa ou têm idéias, mas como propriamente pensantes e Idéias ${ }^{7}$. Neste sentido, aceder ao Saber absoluto, ou antes instaurá-lo, caso em que o Ser-consciente tem que se despojar de suas aparências contingentes, implica em aceder não apenas ao Ser-autoconsciente, mas avançar à Essência e ao Conceito conscientes, bem

Bachmann, Reinhard Heckmann und Rainer Lambrecht. Hamburg: Felix Meiner, 1992, p. 15. Texto citado de ora avante conforme se segue: VLM, 1817, ad § 16, p. 15 (paginação original da edição crítica).

${ }^{4}$ Discutiremos o uso de tais termos e de termos afins na próxima seção do presente trabalho.

${ }^{5}$ Veja-se, Wissenschaft der Logik. Erster Teil: Die objektive Logik. Erster Band: Die Lehre vom Sein (1832), herausgegeben von Friedrich Hogemann und Walter Jaeschke. Hamburg: Felix Meiner, 1985 [GW 21], p. 49, (de ora avante, citaremos esse texto como segue: WdL, I, 1, 1832, p. 49). Análogo a esse será o procedimento seguido para as edições de 1812: Erster Band: Die objektive Logik. Erstes Buch: Die Lehre vom Sein (GW 11, 1978), 1813: Erster Band: Die objektive Logik. Zweites Buch: Die Lehre vom Wesen (GW 11, 1978), e, 1816: Zweiter Band: Die subjektive Logik oder die Lehre vom Begriff (GW 12, 1981), também organizadas por Friedrich Hogemann e Walter Jaeschke.

${ }^{6}$ Ver G. W. F. HEGEL, Grundlinien der Philosophie des Rechts oder Naturrechts und Staatswissenschaft im Grundrisse, mit Hegels eigenhändigen Notizen und den mündlichen Zusätzen. Auf der Grundlage der Werke von 1832-1845 neu edierte Ausgabe. Redaktion Eva Moldenhauer und Karl Markus Michel. Frankfurt am Main: Suhrkamp, 1970 [TWA 7], p. 29. De ora avante citado como se segue: GPhR, § 1, A. [onde '§' refere-se aos parágrafos em tela e 'A' à respectiva Anotação (Anmerkung), quando for o caso, 'Ad.' referir-se-á aos adendos orais (mündliche Zusätze) de Hegel, transcritos por seus discípulos; procedimento também a ser utilizado nas outras obras de Hegel com essas características].

${ }^{7}$ Veja-se, entre outros lugares, G. W. F. HEGEL, Enciclopédia das Ciências Filosóficas em Compêndio (1830), trad. Paulo Meneses e Pe. José Machado, São Paulo: Loyola, 1995, I, p. $69-77$, p. $79-80$; III, p. 207-208, p. 213-214, p. 275-276. Texto citado de ora avante conforme se segue: E., 1830, §§ 20-23, § 24, Ad. 1, § 436 Ad., § 441 Ad., § 482 A.. Ver também, VLM, 1817 , ad $\S 12$, p. $4-5$. 
como daí à Essência e ao Conceito autoconscientes eles mesmos ${ }^{8}$; o que só é possível mediante a autoconstituição e a autoregulação do próprio Especulativo puro segundo seus princípios motores, bem como mediante sua compreensão adequada.

Pela expressão 'princípios motores' designamos aqueles elementos autoconstitutivos e autoregulativos primordiais do Especulativo puro, os quais: (1) constituem seu estado de auto-atividade e, por conseguinte, regulam sua conformação como Universal ativo ${ }^{9}$; bem como, desse modo, (2) impulsionam seu conteúdo a pôr-se a si mesmo em um movimento auto-regulável que forja para si mesmo sua Forma constitutiva e que, assim, (3) permitem ao Especulativo puro produzir-se a si mesmo como "a consciência sobre a forma do automovimento interior de seu conteúdo"10. Assim, o primeiro elemento ou princípio motor se mostra como o Juízo infinito, identificado direta ou indiretamente em diversos momentos pelo próprio Hegel como o Especulativo puro em si ou em geral, expresso na chamada Negação da negação ou na Idéia mesma enquanto a Identidade negativa do Conceito e da objetividade, do infinito e do finito et coetera $^{11}$; contudo, em si ou em geral, o Especulativo puro se apresenta ainda nos limites do conhecer analítico ou, o que é o mesmo, como a primeira premissa do Silogismo especulativo ou, ainda, como a conclusão do primeiro silogismo da Filosofia $^{12}$. O segundo princípio motor do Especulativo puro é a Contradição absoluta - ou que se suprassume a si mesma, de modo a restabelecer a primeira imediatidade -, isto é, o Especulativo puro (posto) para si, a um tempo como unidade e contradição, ou como o Universal e o Particular em sua identidade e oposição recíprocas; por conseguinte, enquanto cindido dentro de si e se determinando em cada um de seus momentos formais e graus de concretude, no âmbito da segunda premissa do silogismo especulativo ou a conclusão do segundo silogismo da Filosofia, como a Totalidade concreta ou a Verdade absoluta

\footnotetext{
${ }^{8}$ Infelizmente, Hegel não sistematiza esse ponto. Na Phänomenologie, além dos termos Serconsciente e Ser-autoconsciente, ele se utiliza apenas dos termos Essência consciente (PhG, $\S 306, \S 430$ (p. 205, p. 283)), e Essência autoconsciente (§ 685, § 780 (p. 452, p. 507). Para os termos Conceito consciente e Conceito autoconsciente, Hegel se serve das expressões "Espírito que se sabe a si mesmo" (PhG, $\S 786$ (p. 513) e "Espírito que se sabe a si mesmo como Espírito" (PhG, $\S 762, \S 808$ (p. 497, p. 531), bem como de Conceito consciente ou Conceito sabido (WdL, I, 1, 1832, p. 33, p. 45) e Conceito pensante ou o Conceito puro que se tem por objeto intencional (WdL, II, 1816, p. 20, p. 252).

${ }^{9}$ Sobre o Universal ativo, veja-se SILVA, M. M.; WUICK, R. O universal ativo e suas determinações fundamentais: uma introdução à leitura especulativa dos $\S \S 20-23$ da Enciclopédia das ciências filosóficas em compêndio (1830) de Hegel. In: Revista Eletrônica Estudos Hegelianos, Recife/PE, v. 04, n. 06, (2007): URL = <http://www.hegelbrasil.org/rev06b.htm $>$. Acesso em janeiro de 2008

${ }^{10} \mathrm{WdL}, \mathrm{I}, 1,1832$, p. 37.

${ }^{11}$ Veja-se, Habilitationstheses (1801), 6. In: G. W. F. HEGEL, Jenaer Schriften (18011807). Auf der Grundlage der Werke von 1832-1845 neu edierte Ausgabe. Redaktion Eva Moldenhauer und Karl Markus Michel. Frankfurt am Main: Suhrkamp, 1983, [TWA 2], p. 533 (citado de ora avante: Habilitationstheses, 6). E ainda: PhG, §§ 344-346, § 537 ss., §§ 790-793 (p. 231-233, p. 534-535 ss., p. 517-519); VLM, ad § 16, p. 15 ss., ad $\S 37$, p. 64-69; WdL, I, 2, 1813, p. 370-372; WdL, II, 1816, p. 25 ss., p. 34-35, p. 69-70, p. 245, p. 253; E., $1830, \S 173, \S \S 213-215$.

${ }^{12}$ Veja-se WdL, II, 1816 , p. 202-204, p. 246, p. 251; E., 1830, § 575.
} 
que se mantém firme na contradição de seus momentos contingentes ${ }^{13}$. Enfim, a expressão adequada de tal Verdade absoluta e da contradição ela mesma, expressão essa cuja forma não é senão a forma do próprio silogismo e, desse modo, o terceiro elemento constitutivo ou princípio motor do Especulativo puro, a saber: (3) a Proposição especulativa, como resultado ou conclusão do silogismo especulativo ou, ainda, do terceiro silogismo da Filosofia ${ }^{14}$.

Temos aqui - nesse terceiro princípio motor - o próprio Especulativo puro em si e para si exprimindo-se em sua identidade negativa absoluta de si consigo mesmo, isto é, como o Místico ${ }^{15}$. Dito de outro modo: a identidade que é o verdadeiro em si, o todo ainda não implementado ou o Uno, e a totalidade consumada - ou o Uno (que se fez Múltiplo) meramente (posto) para si (sob a forma da Díade) que, ao se reconhecer em si e para si, se eleva para além do verdadeiro em si e da totalidade não implementada, se apresentando em seu diferenciar-se e em seu retornar-se dentro de $\mathrm{si}^{16}$-, ou seja, o Si (diferenciado e retornado dentro de si) que é-com o si mesmo (o todo não implementado ou o primeiro si), mas que desse se distingue justamente por ser-com, idêntico e não-idêntico, e não poder ser determinado sem ser-com o si mesmo em absoluto $^{17}$. Assim, perfazendo-se como conclusão do silogismo especulativo ou, mais precisamente, como conclusão do terceiro silogismo da Filosofia, a Proposição especulativa se impõe como o ápice mesmo do que Hegel designara 'tríplice silogismo' ou 'silogismo absoluto' ${ }^{18}$; este em cujo primeiro silogismo, - o silogismo do Dasein, como silogismo analítico -, não só se funda o conhecer analítico e a proposição que o exprime, bem como o modo pelo qual o Sistema da Ciência se torna inteligível ao discurso humano, mas também o modo como se apresenta a primeira premissa do silogismo especulativo (esse, o da necessidade ou da Idéia da Filosofia) ou o Juízo infinito enquanto elemento destruidor da forma da proposição em geral - vale dizer: da proposição analítica ela mesma -, anunciando portanto a Proposição especulativa como tal, mostrando-se como ela própria em sua imediatez, como já o indicara o $§ 61$ da Phänomenologie des Geistes de 1807. Porém, como em sua imediatez a Proposição especulativa ainda não

\footnotetext{
${ }^{13}$ Veja-se Habilitationstheses, 1; PhG, $\S \S 616-631$, $\S 750-756, \S \S 773-785$, $\S \S 794-796$ (p. $405-415$, p. $489-493$, p. 504-513, p. 519-522); E., $1830, \S \S 6-12, \S 25, \S 82, \S 84-85$, $\S 112-114$, $\S 119, \S \S 193-194, \S 381, \S 576$; WdL, I, 2, 1813, p. 279-290, sobretudo, p. 289; WdL, II, 1816, p. 46 , p. $187 \mathrm{ss}$, p. 245-251, em especial, p. 246-247. E ainda o comentário ao $\S 82$ da Enciclopédia de 1830 nas Vorlesungen über die Logik, (Berlin 1831, nachgeschrieben von Karl Hegel. Hrsg. von Udo Rameil unter Mitarbeit von Hans-Christian Lucas, Hamburg: Felix Meiner, 2001, aqui, na versão francesa, G. W. F. HEGEL, Leçons sur la logique (1831), présentation de Jean-Marie Lardic, traduction et notes de jean-Michel Buée et David Wittmann, Paris: Vrin, 2007, p. 87-88 (VL, 1831, § 82, p. 87-88), [paginação da edição alemã].

${ }^{14}$ Ver, Habilitationstheses, 2; PhG, $\S \S 61-66$, § 797 ss. (p. 46-49, p. 522 ss.); VL, 1831, 82 , p. 87-88; WdL, I, 1, 1832, p. 77-80, p. 102-104; WdL II, 1816, p. 246, p. 251; E., 1830, § 181 Ad., $§ 577$.

${ }^{15}$ E., $1830, \S 82$, Ad.

${ }^{16}$ Confronte-se: PROCLUS, Théologie platonicienne, texte établi et traduit par H. D. Saffrey et L. G. Westerink, Paris: Belles Lettres, 2003, II, 6, p. 40-43; III, 8, p. 30-34; III, 12, p. 44-46; III, 14, p. 49-52.

${ }^{17}$ Confronte-se com: $\mathrm{PhG}, \S \S 17-25$ (p. 13-19); WdL II, 1816, p. 247 ss.; E., 1830, $\S \S$ $575-577$.

${ }^{18}$ E., 1830, $\S 187$ Ad., $\S \S 575-577$. Confronte-se com: WdL, II, 1816, p. 251.
} 
se apresenta na unidade perfeita de sua forma e conteúdo, mas sim como a Contradição absoluta entre a unidade da primeira e a diferença do segundo, ela cede lugar - em seu desenvolvimento interior - à proposição transcendental (designada por Hegel como a premissa sintética), na qual o conteúdo especulativo e forma transcendental que o exterioriza se contradizem absolutamente, ao mesmo tempo em que a Verdade objetiva se impõe como identidade absoluta de um e da outra ${ }^{19}$.

A proposição transcendental, concebida enquanto premissa sintética, em seu nível e caráter propriamente ontológico-transcendental, não é senão a proposição dialética, ou racional-negativa, que se impõe como resultado ou conclusão do segundo silogismo da Filosofia - o da Reflexão - e, portanto, se apresentando como a segunda premissa do silogismo especulativo. Esse no qual está em jogo como silogismo da Necessidade - justamente a mediação e a perfeição da Forma (que se sobrepõe ao conteúdo negativo na proposição analítica contradizendo-o formalmente, mas também sendo contraditada realmente ou destruída por este) e do conteúdo negativo (que se sobrepõe à Forma abstrata na proposição transcendental contradizendo-a realmente, sendo por seu turno suprassumido juntamente com ela na Proposição especulativa) ${ }^{20}$. De onde, partindo da identidade formal na primeira e da oposição real na segunda, - ou da distinção analítica (empírica ou semanticamente considerada) do Sujeito e o Predicado da proposição em uma e da síntese a priori (pragmaticamente considerada) de ambos na outra -, o silogismo especulativo ter que resultar na identidade negativa da identidade formal (que se mostra como diferença real) e da oposição real (que se funda na identidade absoluta como sua verdade). Eis aí a chamada identidade da identidade e da não-identidade, o resultado positivo de um procedimento negativo que, enquanto mediação de uma oposição, se conforma como a Proposição especulativa e se impõe como a identidade mesma do sujeito e o predicado ou da subjetividade e a objetividade; proposição essa cuja cópula (ou função) não opera uma simples inerência - tautologia, instanciação ou atribuição - do predicado ao sujeito ou de um conceito determinado a outro, como na proposição analítica ${ }^{21}$, ou uma mera subsunção - determinação, reflexão ou mesmo indiferenciação - do particular sob o universal ou, ainda, entre o conceito e a intuição (na Idéia), como na proposição transcendental ${ }^{22}$. Ao contrário disso, a Proposição especulativa opera a suprassunção ${ }^{23}$ do próprio Conceito (enquanto livre) e o juízo (como sua realidade) - a sobredeterminação de seus momentos e graus segundo sua liberação ou divisão, reconhecimento ou retorno dentro de si e efetivação ou reunião consigo mesmo -, onde o que está em jogo não é senão o conteúdo ou o ser-aí da Forma ou do Universal ativo que, aí, em seu conteúdo, se reconhece em sua efetividade e, com isso, em si e para si, retorna dentro si em si e para si mesmo.

\footnotetext{
${ }^{19}$ Veja-se, WdL, II, 1816, p. 246-247.

${ }^{20}$ Veja-se, PhG, § 61 ss. (p. 46 ss.); WdL, II, 1816, p. 60-77, sobretudo, p. 69-70; p. 245 e p. $246-247$.

${ }^{21}$ Ver, WdL, II, 1816 , p. 47 , p. 58 , p. 60 , p. 72 .

${ }^{22}$ Ver, WdL, II, 1816 , p. 47 , p. 58 , p. 72 , p. 76.

${ }^{23}$ Ver, WdL, I, 1,1812 , p. 58 ; WdL, II, 1816, p. 59, p. 76-77.
} 
Desses três princípios motores apenas o Juízo infinito é tematizado de modo mais consciente na Phänomenologie des Geistes; não obstante, parece ser justamente a partir deste que Hegel se dá conta do caráter operativo dos outros dois e, como que, entrevê - embora de modo ainda nebuloso - a sua função no projeto da apresentação sistemática do Especulativo puro. Como a tematização hegeliana do Saber absoluto - em sentido estrito, nos limites de sua exposição na Phänomenologie des Geistes- poucas vezes foi considerada em sua economia própria, bem como praticamente nunca no âmbito de seu desenvolvimento interior enquanto um dos momentos do desenvolvimento manente do próprio Especulativo puro, objetivamos aqui tão somente evidenciar o uso e o caráter implícitos de tais princípios no que tange à referida instauração. Em suma, pretendemos determinar em que medida os princípios motores acima delineados constituem ou não a estrutura imanente da instauração hegeliana do Saber absoluto.

\section{Posição do Problema:}

Trata-se de pôr em evidência o caráter autoconstitutivo e autoregulativo dos princípios motores do Especulativo puro nos limites de sua instauração fenomenológica enquanto Saber absoluto, isto é, como pano de fundo - implícito - da mesma; ou ainda, de modo mais rigoroso, da determinação da estrutura imanente do Saber absoluto, aliás, do modo como a consciência-de-si do Espírito se torna objeto de sua consciência. Mesmo que ainda sob a aparência contingente de sua figuração espácio-temporal - pois, enquanto figura, o Saber absoluto apresenta-se primeiramente para nós, em um espaço e em um tempo determinados, e não já também necessariamente em si e para si mesmo -, pode-se observar, no desenvolvimento interior do próprio Saber absoluto, a emergência e a operatividade do Juízo infinito, da Contradição absoluta e da Proposição especulativa, tal como acima delineados, conformando a estrutura mesma desse Saber nos quadros da Phänomenologie des Geistes de 1807. Assim, partindo-se da destruição da forma de um saber da Coisa limitado à imediatez do ser e à determinidade, e, nessa destruição, do emergir da forma pela qual o saber sabe a Coisa como o $\mathrm{Si}$ - que "sabe seu saber como a absoluta essencialidade ou (...) o ser pura e simplesmente como o puro querer ou o puro saber" ${ }^{24}$-, avançando ao "saber do agir do Si dentro de si como saber de toda a essencialidade e de todo o ser-ấ" ${ }^{25}$. Em suma, ao Saber absoluto da Essência consciente que se despoja de suas aparências e, desse modo, suprassume seu reportar-se a um ser, ou seu aparecer ${ }^{26}$.

Neste sentido, para uma melhor compreensão do que aqui está em jogo, há que se distinguir neste trabalho entre o uso epistemológico e o uso ontológico dos termos 'Bewusstsein', 'Selbstbewusstsein' e 'Gegenstand'. De onde, por um lado, os mesmos serem vertidos, em determinados contextos, por 'Serconsciente', 'Ser-autoconsciente' e 'objeto intencional'; com o que pretendemos

\footnotetext{
${ }^{24} \mathrm{PhG}, \S 792$ (p. 518).

${ }^{25} \mathrm{PhG}, \S 798$ (p. 523).

${ }^{26} \mathrm{WdL}, \mathrm{I}, 1,1812$, p. 32; WdL, I, 1, 1832, p.49.
} 
destacar a cisão que se impõe no seio mesmo do Ser, de um lado, como ser subjetivo ou consciente e, de outro, como ser objetivo ou representado, intencionado pelo Ser-consciente que tem "consciência de" ou permanece nesse estado enquanto "é consciente de". Por outro, também a manutenção do termo "Consciência' - para 'Bewusstsein' - no que tange à necessidade de acentuar-se o aspecto ontológico-substancial da Consciência [enquanto Conscientia, Mitwissen] em contraste com o meramente epistêmico, mais afeito ao objeto por ela intencionado, e o simplesmente categorial, no qual a mesma se limitaria a uma simples propriedade do Ser-consciente. Por isso, em conseqüência, ainda no tocante à acentuação do aspecto ontológico-substancial, ora verter-se 'Selbstbewusstsein' por 'Consciência-de-si', ora por 'Autoconsciência'; com o que 'Consciência-desi' não exprimirá senão o trânsito da Consciência à Autoconsciência ou a sua mediação enquanto determinações ontológicas (a primeira formal e a segunda transcendental) no seio das quais se opera a cisão e a reunião de certeza e verdade ou de ser e saber - fazendo jus às diversas passagens em que Hegel se utiliza das expressões 'Bewusstsein über sich', 'Bewusstsein seiner' e 'Bewusstsein von sich'27. O que também justifica o fato da intencionalidade do objeto intencional mostrar-se além da pura e simples determinação epistêmica, portanto como determinação teleológica, tão somente na medida em que se constitui como objeto do Ser-autoconsciente (Selbstbewusstsein) e não mais do simples Ser-consciente.

Da mesma forma, não obstante, há que se considerar - ainda - certas observações do próprio Hegel, pronunciadas de modo explícito e consciente ou constatadas a partir do texto que ora temos diante dos olhos. A saber: (1) $\mathrm{O}$ estado de inacabamento da Phänomenologie des Geistes, no caso, a maior carência-de-forma (die grössere Unform) de suas últimas partes, sobretudo o capítulo intitulado 'das absolute Wissen'; fato já constatado e reconhecido pelo filósofo de Iena em $1^{0}$ de maio de $1807^{27}$, antes mesmo da distribuição de sua obra. (2) A distinção, ou melhor, a carência de distinção e maior precisão, entre a figura do Saber absoluto ou sua figuração espácio-temporal (ainda que como figura do Espírito ou de um mundo) e o Saber absoluto propriamente dito ${ }^{28}$, a configuração puramente especulativa das essencialidades espirituais; de outro modo, entre a sua compreensão fenomenológica ou segundo a consciência em geral (limitada à representação de si mesmo do Espírito para si ${ }^{29}$, e, por conseguinte, em última instância, à separação entre o imanente e o transcendente) e a sua compreensão lógico-efetiva ou segundo o Espírito livre em sua efetividade. (3) O fato de que "o Espírito é em si o movimento que é o conhecer" e a constatação desse movimento enquanto "o círculo que retorna dentro si, que pressupõe seu começo e que só o atinge no fim" ${ }^{30}$; isso, ao mesmo tempo em que, (4) se impõe como a transformação do Em-si no Para-si (da Substância em Sujeito) ou, o que é a mesma coisa, como a suprassunção de tal movimento, na

\footnotetext{
${ }^{27}$ Veja-se, entre outros lugares, $\mathrm{PhG}, \S \S 684,736,749,759,787$ (p. 450, 480, 489, 494, 513).

${ }^{28}$ G. W. F. HEGEL, Briefe von und an Hegel, Band I: 1785-1812, Hg. von Johannes Hoffmeister, Berlin: Akademie Verlag, 1970, p. 161-162 [citado de ora avante, em seus três tomos, conforme se segue: Briefe, I, p. 161-162].

${ }^{29} \mathrm{PhG}, \S 438$ (p. 288).

${ }^{30} \mathrm{PhG}, \S 802($ p. 525$)$
} 
medida em que o Espírito se consuma em si, como Espírito do mundo, e assim atinge sua perfeição como Espírito autoconscientei ${ }^{31}$.

Essas observações indicam-nos a plausibilidade de duas leituras igualmente possíveis, mas reciprocamente opostas, em torno do capítulo final da Phänomenologie des Geistes. Por um lado, de acordo com a primeira, o fim da Phänomenologie não seria senão o seu começo, de modo que o Saber absoluto terminaria por sempre recair no tempo ou ter que se manifestar como saber fenomenal; com o que essa poderia ser considerada como a típica leitura fenomenológica, para a qual, fundada no postulado da pressuposição mútua do lógico e o fenomenológico, a Fenomenologia se mostraria como uma esfera autônoma, propriamente existencial, onde as essencialidades lógicas consumariam sua efetividade. Por outro lado, de acordo com a segunda, o fim da Phänomenologie des Geistes seria mais propriamente o começo da Wissenschaft der Logik, da suprassunção do objeto intencional no conceito ou da substância no sujeito, iniciando portanto um novo percurso, que, como tal, não mais necessitaria manifestar-se temporalmente; de onde, mediante a distinção da figura do Saber absoluto e o Saber absoluto propriaPhG, $\S 808$ (p. 530). mente dito, ou o Saber absoluto em si e o Saber absoluto em si e para si, a suprassunção da própria Fenomenologia enquanto esfera autônoma. No que tange à segunda leitura, a única aqui a ser explicitada e a que - a nosso ver - se mostra mais adequada ao ponto de vista especulativo, se nos impõem três implicações: (1) o despojamento da Consciência em relação às suas aparências ${ }^{32} ;(2)$ a liberação do objeto intencional do Serconsciente com respeito à cisão entre sujeito cognoscente e objeto cognoscível ou entre saber e ser sabido ${ }^{33}$; (3) a suprassunção, pela essência, do seu reportar-se a um ser ou de seu aparecer, de modo que em sua determinação ela não seja mais exterior e sim o subjetivo autônomo livre, ou antes o sujeito mesmo ${ }^{34}$. O que nos impõe a exigência de princípios motores imanentes ao processo do despojamento, liberação e suprassunção, mediante os quais o Sujeito livre não só se põe como tal, mas também se desenvolve; melhor, tais princípios constituem a estrutura do seu pôr-se e do seu desenvolver-se a si mesmo enquanto efetividade livre, para além do fenomenológico.

O despojamento das aparências contingentes e a liberação do objeto intencional com respeito ao Ser-consciente em geral exigem antes de tudo que tanto a natureza quanto a forma do juízo e da proposição em geral sejam destruídos, destruição essa unicamente pela qual "a reflexão da Singularidade dentro de si mesma" põe essa Singularidade, enquanto Singularidade que se põe a si mesma, como a Determinidade determinada [ou a Negatividade negada] ou o Singular que, assim, "é posto como se continuando em seu predicado, que com ele é idêntico" 35 . Pois bem, a referida destruição é obra do Juízo infinito - aqui considerado como o primeiro princípio motor do Especulativo puro -, o qual, por um lado, como Juízo positivamente infinito, consiste na afirmação imediata

\footnotetext{
${ }^{31} \mathrm{PhG}, \S 802$ (р. 525).

${ }^{32}$ Ver PhG $\S 89, \S 683, \S 801$ (p. 68, p. 450, p. 524).

${ }^{33}$ Ver WdL, I, 1, 1812, p. 21; WdL, I, 1, 1832, p. 33.

${ }^{34}$ Ver WdL, I, 1, 1812, p. 32; WdL, I, 1, 1832, p. 49.

${ }^{35} \mathrm{WdL}, \mathrm{II}, 1816$, p. 70.
} 
do Especulativo puro como o Racional positivo ou o Afirmativo que está contido na dissolução das determinações em sua oposição e na passagem de uma a outra $^{36}$, e, por outro, como Juízo negativamente infinito, consiste na manutenção firme de si mesmo do Especulativo puro na medida em que ele e só ele é capaz de manter firme a Contradição absoluta ${ }^{37}$ - aqui considerada como desdobramento do Juízo negativamente infinito e, com isso, o segundo princípio motor do Especulativo puro - na qual e pela qual ele se mantém firme, afirmando-se ou sobredeterminando-se a si mesmo enquanto o Positivo racional ou, o que é o mesmo, o Racional positivo. Enfim, já que a destruição acima referida é obra do Juízo infinito, a expressão deste tem que se pôr ao encargo da Proposição especulativa - aqui, enquanto consecução dos dois momentos anteriores do Juízo infinito e sua expressão última como Juízo infinitamente infinito, considerada como o terceiro e último princípio motor do Especulativo puro -, na qual o Singular, que "é posto como se continuando em seu predicado, que com ele é idêntico" e assim se afirma em sua identidade negativa com o seu outro, encontra finalmente sua expressão adequada, vale dizer, absoluta.

Embora Hegel ele mesmo não tenha sistematizado tais princípios motores no sentido em que acima se buscou esboçar, todo o seu System der Wissenschaft é concebido segundo a operatividade autoconstitutiva e autoregulativa dos mesmos $^{38}$ - ainda que em grande parte isso se apresente apenas de modo pressuposto, de onde certa permanência do "para nós", como ocorre, por exemplo, no caso da Phänomenologie des Geistes de 1807 em geral e no capítulo sobre o Saber absoluto em especial. O que é confirmado tanto na Lógica em seu conjunto - concebida enquanto Ciência subjetiva e primeira ${ }^{39}$-, na medida em que aí "o conhecer, já contido na Idéia lógica simples, é apenas o conceito, por nós pensado, do conhecer; não o conhecer para si mesmo, nem o Espírito efetivo, mas simplesmente sua possibilidade" 40 ; quanto em sua primeira parte - aqui, em nosso caso, no âmbito da Lógica concebida como Ciência objetiva e universal real ou última ${ }^{41}$-, na medida em que a Lógica objetiva é ainda a esfera do conceito em si ou para nós e do conceito posto por nós e não já do Conceito em si e para si, em si e para si mesmo, esse, como tal, já verificado pela Filosofia do espírito (essa, como a ciência que conclui a esfera do primeiro silogismo, media a do segundo e abre a do terceiro $)^{42}$. Neste sentido, para além das simples estruturas aparentes cujo lugar não é senão a esfera fenomenológica, em especial

\footnotetext{
${ }^{36}$ VLM, 1817, ad. 16, p. 15; E., 1830, § 82.

${ }^{37} \mathrm{WdL}, \mathrm{I}, 2$, 1813, p. 289.

${ }^{38}$ Veja-se, a respeito, o verdadeiro programa esboçado na anotação ao $\S 17$ da Encyklopädie de 1817: G. W. F. HEGEL, Encyklopädie der philosophischen Wissenschaften im Grundrisse (1817). In: G. W. F. HEGEL, Encyklopädie der philosophischen Wissenschaften im Grundrisse und andere Schriften aus der Heidelberg Zeit, neue herausgegeben von Hermann Glockner, Heidelberg: Frommanns Verlag, 1956, p. 37-38. Texto citado de ora avante conforme se segue: E., 1817, § 17, A. [onde ,A' indica as Anmerkungen - anotações - de Hegel]. Confronte-se com: E., 1817, §§ 475-477; E., 1830, § 187 Ad., §§ 575-577; WdL, II, 1816, p. 246-248, p. 251.

${ }^{39}$ E., 1817, § 17 A.; WdL, II, 1816, p. 198, p. 253.

${ }^{40} \mathrm{E} ., 1830, \S 381$ Ad.

${ }^{41}$ E., 1817, § 17 A., $\S ~ 475-477 ;$ WdL, II, 1816, p. 198.; E., 1830, § 381 Ad., §§ 575-577.

${ }^{42}$ Veja-se, E., 1830, § 84, § 112, § 162 A. Confronte-se com: PhG, § 25 (p. 22)
} 
do próprio Saber absoluto enquanto a última figura do Espírito, como tal explicitada na afirmação hegeliana segundo a qual "o Saber absoluto é o Espírito que se sabe em figura-de-espírito ou o saber conceituante" 43 , na qual infelizmente ainda se deixa persistir certa ambigüidade entre o Saber absoluto ele mesmo ou "o Espírito que se sabe como Espírito" e a sua figura fenomenológica ou "o Espírito que se sabe em figura-de-espírito", o que está em jogo não é senão a forma ou a necessidade interior na qual a efetividade do Espírito livre, oculta sob a aparência contingente, se conforma. De onde, por fim, no âmbito do Saber absoluto propriamente dito e não no de sua figura fenomenológica, a questão que ora se nos apresenta consistir, sobretudo, em saber a medida mesma em que a consciência-de-si do Espírito se torna objeto de sua própria consciência.

Rigorosamente considerado, o capítulo intitulado O Saber absoluto constitui o quarto momento (DD) da Seção (C) Razão. Em sentido especulativo antecipando de certo modo o próprio Especulativo, que se apresenta em geral como o resultado positivo da Dialética e, portando, como distinto do Dialético -, isto significa que o Saber absoluto enquanto tal distingue-se positivamente do momento a ele imediatamente anterior - (CC) A Religião -, que, por seu turno, cumpre a tarefa de um resultado negativo, aqui no sentido de uma reconciliação da Consciência e da Autoconsciência limitada à forma do ser-em-si ${ }^{44}$, excluindo portanto a reconciliação que se deu na forma do ser-para-si, própria da Consciência em geral, da qual a própria Razão ${ }^{45}$ - (AA) Razão -, enquanto primeiro momento do Saber absoluto ${ }^{46}$, se origina; essa última a reconciliação que se dá no plano Espírito certo de si mesmo ${ }^{47}$. Por isso, para que a reconciliação a ser operada no Saber absoluto seja ela mesma absoluta, haverá que se retomarem primeiramente os momentos do périplo fenomenológico, sobretudo em sua estrutura profunda, de modo que se possa mediar adequadamente essas duas formas excludentes de reconciliação.

Tal estrutura comporta uma tríplice articulação, onde cada articulação se mostra sob pelo menos três níveis estruturais distintos. Primeiramente, nos limites dos $\S \S 788-797$, a única articulação aqui a ser considerada, Hegel como que retoma ou rememora a emergência dos princípios motores apresentados mais acima. Pode-se dizer que o $\S 788$ apresenta-se aí como um primeiro nível estrutural, no qual está em questão justamente a necessidade da superação do Ser-consciente como tal e a exigência da consciência-de-si efetiva do Espírito tornar-se objeto intencional de sua consciência; nos §§ 789-796 está em jogo o segundo e o mais importante nível estrutural, cujo objeto é a suprassunção da forma da objetividade epistêmica e do objeto intencionado pela Consciência em geral, dando assim lugar ao Si enquanto objeto intencional do Ser-autoconsciente e à própria consciência-de-si do Espírito como objeto intencional da consciência

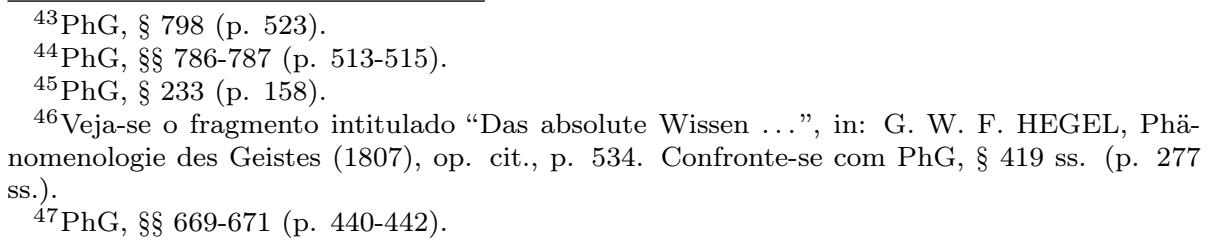


deste. De onde, a título de conclusão dessa primeira articulação, a instauração - no § 797 - daquilo que poderíamos designar o terceiro nível estrutural, que se constitui como a constatação do fato da consciência-de-si do Espírito tornarse objeto intencional de sua consciência ou do Saber absoluto que se põe a si mesmo, o estabelecimento do conceito da Ciência pura; ainda que neste momento, ao que tudo indica, apenas para o sujeito filosofante. Mas com isso, não obstante, também emerge a segunda articulação fundamental, nos $\S \S 798-804$, onde estará em jogo a plena liberação do conteúdo especulativo em relação à forma meramente representativa - ou simplesmente figurativa - na qual até então ele se encontrava e, como que, sempre tende a recair; tal é, já no âmbito do Saber absoluto mesmo, embora ainda em parte submetido a uma estrutura fenomenológica, a esfera intermediária entre o Lógico puro e o fenomenológico, na qual a exigência primeira não será senão a eliminação do tempo, isto é, da esfera na qual o fenomenológico se impõe. Enfim, nos $\S \S 805-808$, a terceira e última articulação fundamental se faz presente, trata-se aí de sua própria autocompreensão a um só tempo como conteúdo puramente especulativo e efetividade espiritual propriamente dita; de onde podermos designá-lo como lógico-efetivo ou o conteúdo que se desenvolve em sua efetividade enquanto a necessidade interior sob a aparência da contingência.

Ora, tanto a estrutura aludida quanto suas três articulações fundamentais não são senão os modos pelos quais - nos limites da exposição hegeliana do Saber absoluto - os princípios motores do Especulativo puro forjam sua instauração. Assim, por um lado, de acordo com a macro-estrutura da referida exposição, o Juízo infinito apresentar-se-á de modo predominante na primeira articulação, a Contradição absoluta na segunda e a Proposição especulativa na terceira; por outro lado, de acordo com a micro-estrutura de tal exposição, cada uma das articulações fundamentais citadas deve comportar um tipo de consideração em torno dos princípios motores tomados em seu conjunto e, neste sentido, pode-se adiantar, cada uma no âmbito de um dos silogismos da Filosofia e conformandose como premissas e conclusão do silogismo total. Infelizmente, muito em função do estado inacabado desse que é o capítulo final da Phänomenologie des Gesites, mas também em função dos modos como ele foi lido até aqui, nada do que estamos a dizer parece evidente a uma leitura direta do texto hegeliano, pelo menos sem levar em conta o arcabouço da compreensão que o próprio Hegel nos legara de sua obra e que se encontra esparso em diversos lugares de suas obras posteriores à Phänomenologie; por isso, ao invés de uma explicitação da estrutura profunda de todo o capítulo em questão, nos limitaremos a indicar nos limites da primeira articulação fundamental de tal estrutura - tão somente as referências aos princípios motores (ou, de modo ainda mais específico, apenas ao primeiro princípio motor) do Especulativo puro no âmbito da instauração fenomenológica deste enquanto Saber absoluto. Com isso, poder-se-á pelo menos constatar que tais referências não são nem fortuitas nem utilizadas de modo inconsciente, mas são elas próprias necessárias à instauração do Saber absoluto e a necessidade interior ela mesma de seu desenvolvimento lógico-efetivo.

Assim, limitar-nos-emos aqui tão só a explicitar a exigência mesma, como tal ainda não realizada no âmbito da exposição hegeliana do Saber absoluto, 
de tais princípios motores. Neste sentido, explicitaremos o que consideramos as articulações básicas da instauração do Saber absoluto no capítulo final da Phänomenologie des Geistes nos quadros da retomada e desenvolvimento dos princípios motores do Juízo infinito e da Contradição absoluta tal como eles emergem nos momentos precedentes da Razão em sua passagem de observadora a ativa (em AA) e da pura Inteligência e sua expansão no Iluminismo [em (BB) O Espírito] para o primeiro ${ }^{48}$, bem como nos momentos da Distorção da Consciência moral (em BB), da morte de Deus e da oposição entre o Bem e o Mal na Religião revelada (em CC) para o segundo ${ }^{49}$. No caso do segundo princípio motor, nos limitaremos a delinear certos aspectos mais gerais de seu desenvolvimento e as linhas fundamentais mediante as quais se estrutura a passagem do Juízo infinito à Proposição especulativa, bem como sua expressão no movimento das reconciliações parciais e opostas à reconciliação absoluta. Quanto ao terceiro princípio motor, o da Proposição especulativa, embora dele Hegel se aproxime em diversos momentos do périplo fenomenológico, no corpo mesmo da Phänomenologie des Geistes ele só é atingido - enquanto princípio motor -, e isso também de modo implícito, no momento da instauração do Saber absoluto ${ }^{50}$; de onde, aqui, nos limitarmos à apresentação do processo de sua emergência mesma.

\section{Do Saber absoluto, ou de como a conscPhG, § 808 (p. 530). iência-de-si efetiva do Espírito tornar-se objeto de sua consciência}

Passemos então à explicitação dos princípios motores do Especulativo puro nos limites da instauração fenomenológica do próprio Especulativo puro enquanto Saber absoluto; isso a partir de um caso concreto, a saber, o de como a consciência-de-si do Espírito se torna objeto de sua consciência ou de como o Saber absoluto se instaura. Tomaremos em questão o que consideramos como os seguintes níveis estruturais: (1) a necessidade da superação do Ser-consciente como tal e a exigência da consciência-de-si efetiva do Espírito tornar-se objeto intencional de sua consciência; (2) a suprassunção da forma da objetividade epistêmica e do objeto intencionado pela Consciência em geral, dando lugar ao Si enquanto objeto intencional do Ser-autoconsciente e à própria consciênciade-si do Espírito como objeto intencional da consciência deste; de onde, (3) mediante o fato da consciência-de-si do Espírito tornar-se objeto intencional de sua consciência ou do Saber absoluto que se põe a si mesmo, o estabelecimento do conceito da Ciência pura. Assim, esperamos demonstrar que o próprio Saber absoluto só pode se instaurar mediante a emergência dos princípios motores acima referidos.

O primeiro nível estrutural - (1) a necessidade da superação do Ser-consciente como tal e a exigência da consciência-de-si efetiva do Espírito tornar-se objeto

\footnotetext{
${ }^{48} \mathrm{PhG}, \S \S 344-346, \S 537$ ss., $\S \S 790-793$ (p. 231-233, p. 534-535 ss., p. 517-519).

${ }^{49} \mathrm{PhG}, \S \S 616-631, \S \S 750-756, \S \S 773-785, \S \S 794-796$ (p. 405-415, p. 489-493, p. 504-513, p. $519-522)$

${ }^{50} \mathrm{PhG}, \S 797$ ss. (p. 522 ss.).
} 
intencional de sua consciência - exige basicamente que se vá além da representação, que constitui o meio-termo entre o puro pensar e o Ser-autoconsciente como tal, e do vai e vem no qual ela se move ${ }^{51}$. Tal exigência se realizará tão somente a partir de quando o Espírito atingir o Conceito, ganhando-o, podendo assim desenvolver o ser-aí e o movimento (que são os seus) no próprio Conceito - esse éter de sua vida - e ser Ciência; quando reunirá em sua unidade imediata a forma objetiva da verdade e a forma do Si que se sabe; de onde, pelo fato de haverem se liberado de sua manifestação na Consciência e dependerem de ora avante apenas da pura determinidade do Conceito e seu movimento, os momentos de seu desenvolvimento não mais portarem a diferença entre o saber e a verdade ${ }^{52}$. O que, ao fim e ao cabo - no ato mesmo da realização da referida exigência -, implica em que aquela diferença entre o saber e a verdade esteja suprassumida, bem como a tarefa da Phänomenologie des Geistes plenamente realizada; razão pela qual - no que tange ao ponto de vista que a preside - a própria Phänomenologie apresentar-se a partir deste ato também suprassumida.

Em vista disso, já no inicio do capítulo final de sua Phänomenologie des Geistes, mais especificamente em seu primeiro parágrafo ${ }^{53}$. Hegel constata que "o Espírito da religião revelada ainda não ultrapassou sua consciência como tal, ou, o que é o mesmo, [que] sua consciência-de-si efetiva não é o objeto de sua consciência" ${ }^{4}$. Ora, dizer que "o Espírito da religião revelada ainda não ultrapassou sua Consciência como tal" ou que "sua consciência-de-si efetiva não é o objeto de sua consciência" implica em se reconhecer que tal Espírito: (1) não só ainda permanece circunscrito ao Ser-consciente como tal, mas também (2) que a sua consciência se limita ao "ponto de vista do Ser-consciente, que é [meramente] consciente da essência absoluta" ${ }^{55}$, próprio das quatro primeiras figuras tratadas anteriormente - antes da Consciência religiosa - no decorrer da exposição fenomenológica ${ }^{56}$; bem como, com isso, (3) que o Espírito da religião revelada não só ainda permanece ao nível da mera "consciência da essência absoluta em geral", da essência absoluta aparecendo em si e para si ou como a consciência-de-si do Espírito ${ }^{57}$, própria da figura da Religião, mas também que, (4) ao nível da unificação da consciência do Espírito em geral e a consciênciade-si do Espírito em particular, (a) se limita ao simples Espírito consciente de si como Espírito, a Autoconsciência que, como Ser-consciente, tem a si mesma por objeto intencional, e que: (b) enquanto Espírito unificado em si, do lado do Espírito religioso, permanece meramente "em si, ou segundo seu conteúdo absoluto", (c) enquanto unificado para si, do lado do próprio Ser-consciente como

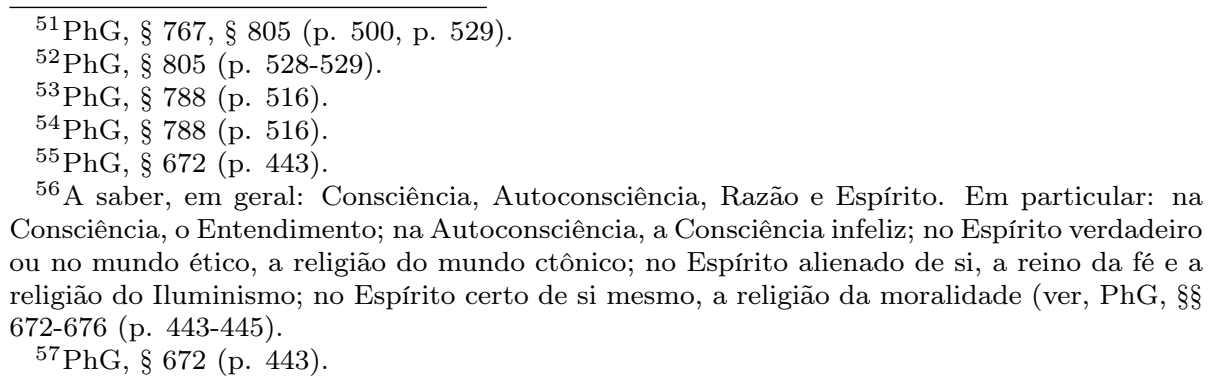


tal, permanece meramente "para si, segundo sua forma carente-de-conteúdo" ou, o que é o mesmo, segundo o lado da consciência-de-si enquanto circunscrita à forma da imediatez própria do Ser-consciente como tal ${ }^{58}$. De onde, como dirá o próprio Hegel, sua limitação ao "Espírito em geral" e aos "momentos que nele se distinguem" de um lado, e, de outro, justamente por causa dessa limitação, sua incidência no representar e na forma da objetividade epistêmica ou intencionada.

Quanto a isso, Hegel ele mesmo nos explica que "esse Espírito em geral, e os momentos que nele se distinguem, incidem no representar e na forma da objetividade intencionada. O conteúdo do representar é o Espírito absoluto, e o que resta ainda a fazer é só o suprassumir dessa mera forma, ou melhor, já que ela pertence à Consciência como tal, sua verdade deve já se ter mostrado nas figuras da Consciência"59. Pois bem, justamente porque o conteúdo do representar é o próprio Espírito absoluto, que não obstante é tomado, segundo a forma da objetividade intencionada pertencente à Consciência como tal, apenas enquanto a essência absoluta ou, o que é o mesmo, o conteúdo que, como Autoconsciência, ainda não é para si uma efetividade livre, nem permanece - como Consciência - consciente-de-si mesmo enquanto Espírito absoluto ${ }^{60}$, tal conteúdo e a mera forma da objetividade intencionada pela qual ele é representado terminam por se contradizer na medida mesma em que aí está em jogo tão somente o conteúdo ou a forma do representar de um outro e não já o agir próprio do Si. De onde a necessidade do suprassumir dessa mera forma do representar, que se deve levar a cabo mediante a superação do objeto da Consciência não como algo unilateral, ou fazendo com que o objeto intencional se mostre como retornado ao $\mathrm{Si}$, mas sim, de modo que o objeto intencional se apresente ao $\mathrm{Si}$ como evanescente; isso, na medida em que a extrusão da Autoconsciência, ao romper as diversas camadas de figurações sensíveis ou espácio-temporais nas quais o seu Si se ocultava, o põe como a coisidade mesma frente a qual o objeto da Consciência se dissolve, dando lugar ao Si enquanto objeto da Consciência-de-si e à própria consciência-de-si do Espírito como objeto de sua consciência. Isso quer dizer que agora, no plano da instauração efetiva do Saber absoluto, a consciência do Espírito não pode mais se limitar ao simples Espírito consciente de si como Espírito, meramente "em si, ou segundo seu conteúdo absoluto" ou "para si, segundo sua forma carente-de-conteúdo"61, mas tem de levar a cabo a reconciliação mesma da Consciência com a Autoconsciência tanto na forma do ser-em-si como na forma do ser-para-si, isto é, do Espírito que é em si e para si, em si e para si mesmo ${ }^{62}$.

Trata-se portanto de uma mediação entre as seções (BB) O Espírito e (CC) A Religião, nas quais a reconciliação da Consciência com a Consciência-de-si já ocorrera de modo preliminar; no segundo caso na forma do ser-em-si ${ }^{63}$, no

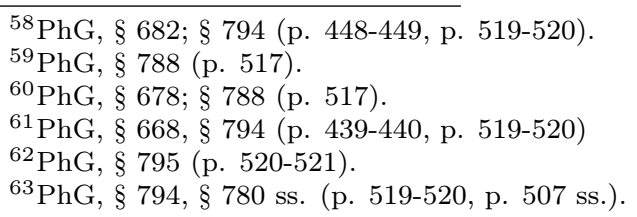


primeiro sob a forma do ser-para-si ${ }^{64}$. Em "(BB) O Espírito" está em jogo o vir-a-ser do Espírito que se sabe segundo sua verdade enquanto resultado da reconciliação entre o Espírito efetivo e o que se sabe como Espírito, isto é, o Espírito consciente e o Espírito autoconsciente, ou ainda, entre si mesmo como Consciência e como Autoconsciência. Contudo, a reconciliação que aí tem lugar é meramente abstrata; pois, embora se elevando ao saber de si mesmo em sua verdade, o Espírito só se sabe assim na medida em que se efetua negativamente, como carente-de-efetividade ou mesmo de Espírito, vivendo portanto "na contradição entre seu puro si e a necessidade que ele tem de extrusar-se para ser e converter-se em efetividade"65. Já em "(CC) A Religião" está em jogo a medida mesma segundo a qual a diferença do Espírito em sua consciência e o Espírito em sua autoconsciência retornará ao Espírito como essência absoluta, que se sabe consciente de si e aí essente, isto é, de como aquela essência abstrata, que em (BB) apenas se apresenta como devendo ser, poderá ser preenchida segundo sua própria efetividade ou pelo Espírito ele mesmo. Nesse caso, a reconciliação levada a cabo - na Religião revelada - entre a consciência e a cutoconsciência do Espírito se mostra sob a forma de um efetuar-se em si da unidade da essência e do Si, segundo a significação positiva da unidade de si com a essência; de onde, porém, ao contrário da inefetividade da reconciliação anterior, o conteúdo da consciência-de-si não se apresentar a ela apenas como objeto ou como o que é-aí, mas também como o Espírito efetivo. Este, não obstante constituir-se como o verdadeiro conteúdo absoluto e a Autoconsciência absoluta ela mesma, não é para a consciência piedosa nada mais que um outro, o qual, como objeto do representar, embora a ela se revele enquanto essência absoluta e com ela se reconcilie sob a forma do sentimento, não é por ela apreendido ou conceituado, permanecendo portanto ainda cindido em sua consciência, ainda não contemplado como objeto imediato efetivo e, por conseguinte, ainda rompido com a efetividade. Enfim, embora em si o mundo esteja reconciliado com a essência, o mesmo não foi ainda transfigurado; pois o Em-si, ou o lado da pura mediação, permanece ainda a reconciliação residente além ou o conteúdo absoluto que como objeto do representar - ainda não é posto pela consciência-de-si como a si mesma e, assim, como ainda não é a consciência-de-si que se põe como objeto para si mesma, permanece fora da unidade do ser-para-si. O que poderá ocorrer tão somente com a suprassunção da forma da objetividade epistêmica e do objeto intencionado pela Consciência em geral, dando lugar ao Si como objeto intencional do Ser-autoconsciente e à própria Consciência-de-si do Espírito como objeto intencional da consciência deste.

A exigência da reconciliação mesma da Consciência com a Autoconsciência a um só tempo na forma do ser-em-si e na do ser-para-si é justamente o que constitui a passagem ao segundo nível estrutural - (2) a suprassunção da forma da objetividade epistêmica e do objeto intencionado pela Consciência em geral, dando lugar ao $\mathrm{Si}$ enquanto objeto intencional do Ser-autoconsciente e à própria consciência-de-si do Espírito como objeto intencional da consciência deste - da

\footnotetext{
${ }^{64} \mathrm{PhG}, \S 682 ; \S 668$ ss. (p. 448-449, p. 439 ss.).
}

${ }^{65} \mathrm{PhG}, \S 668$ (p. 439-440). 
instauração do Saber absoluto ou, o que é o mesmo, a emergência dos princípios motores do Especulativo puro nos limites da instauração fenomenológica do próprio Especulativo puro enquanto Saber absoluto. Trata-se aqui, portanto, de levar a sério em que medida a já citada "reconciliação mesma da Consciência com a Autoconsciência, tanto na forma do ser-em-si como na forma do ser-para-si segundo sua verdade" se realiza em sua efetividade ou em que medida o Espírito da comunidade, em cujo ser-para-si abstrato sua consciência imediata separa-se de sua consciência religiosa, se reconhece nesta como o ser-em-si absoluto de ambas - ou a sua unidade em-si - marchando rumo a sua realização tornando-se igualmente ser-para-si absoluto. Isso porque, embora a distinção entre a consciência do Espírito, ou o Espírito efetivo, e a consciência-de-si do Espírito, ou o Espírito que se sabe como Espírito, em si esteja suprassumida no "Espírito que se sabe segundo sua verdade", essa suprassunção constitui-se aí em um ser-para-si ainda simplesmente abstrato, imediato, em suma: em si ou para nós; em outras palavras, a consciência-de-si efetiva do Espírito ainda não se tornou objeto de sua consciência, essa que se limita a tomar por objeto a Autoconsciência imediata; isto é, abstrata ou ainda fenomênica. Ora, se tal reconciliação só pode ocorrer na medida em que a consciência-de-si efetiva do Espírito se tornar objeto de sua consciência, então ela só pode ocorrer na medida mesma em que "a extrusão da consciência-de-si põe a coisidade" e "essa extrusão não tenha somente a significação negativa, mas também a positiva; não só para nós ou em-si, mas para ela mesma". 66 Vale dizer, nas palavras de Hegel, na medida em que ela "se extrusa a si mesma e nessa extrusão se põe como objeto ou põe o objeto como a si mesma em razão da inseparável unidade do ser-para-si", ao mesmo tempo em que suprassume e recupera dentro de si essa extrusão e objetividade intencionada, estando assim junto de si no ser-outro como tal ${ }^{67}$. Por conseguinte, para levar a termo a referida reconciliação, há que se suprassumir não só o ponto de vista da representação e da consciência como tal, mas também a separação entre o "para nós" e o "para a consciência", enquanto os modos pelos quais o "em si" e o "para si" se apresentam de imediato (ou em geral) ao filósofo; o que, infelizmente, não parece encontrar uma solução adequada na concepção do Saber absoluto como o "Espírito que se sabe em figura-de-espírito".

Isso porque, dizer que "o Saber absoluto é o Espírito que se sabe em figurade-espírito" consiste tão só em apreendê-lo em sua imediatez, como que deixando intacta a "forma do ser-em-si" em sua oposição à "forma do ser-para-si segundo sua verdade" no que diz respeito ao fato de que no primeiro caso está em jogo "para nós" o modo como a Coisa mesma se desenvolve no segundo; de onde, ao fim e ao cabo, ainda que não limite o Espírito ao plano meramente fenomênico (o das figuras da Consciência), o circunscreve à esfera fenomenológica (ao fenomenológico propriamente dito enquanto plano das figuras do Espírito). Por conseguinte, há que se passar à compreensão do Saber absoluto enquanto "o Espírito que se sabe como Espírito" não apenas a título de meta, mas enquanto

\footnotetext{
${ }^{66} \mathrm{PhG}, \S 788$ (p. 517).
}

${ }^{67} \mathrm{PhG}, \S 788$ (p. 517). 
identidade negativa do sujeito filosofante, como que do Espírito que se sabe a si mesmo como Espírito, e da consciência agora despojada de sua aparência. Para o que se fará necessário averiguar a forma interior ela mesma da exposição hegeliana do Saber absoluto e a necessidade, já aí imposta, de se destruir a forma da proposição em geral e instaurar a Proposição especulativa; isto é, mais rigorosamente, considerar em que medida instaura-se já aí aquela necessidade interior - cuja esfera "é o ponto supremo do Ser e da Essência" e que "em si e para si mesma passa à liberdade do Conceito, a identidade interior [que] passa em sua manifestação [Manifestation], que é o Conceito como Conceito"68 - na qual a efetividade do Espírito livre, oculta sob a aparência contingente ${ }^{69}$, se conforma. De onde, enfim, se a consciência-de-si do Espírito tem que se tornar objeto da consciência do Espírito, isso não poderá significar senão que também aqui - na esfera fenomenológica - a necessidade (do movimento lógico-efetivo aí em jogo e seus momentos) tem que ser considerada como a realidade (Realität) ou o objeto intencional do Conceito ao qual ela passa, tal como este enquanto objeto intencional de si mesmo ${ }^{70}$.

Neste sentido, a própria noção de objeto intencional (Gegenstand) tem que ser aqui matizada; pois este não mais será - de ora avante - um objeto intencionado pelo Ser-consciente e que deste se difere, mas será o Ser-autoconsciente ele mesmo enquanto se põe a si mesmo como objeto intencional de si mesmo (não apenas a título teórico, mas fundamentalmente a título prático; portanto, nem formal nem transcendental, semântico ou pragmático, mas especulativamente). Por isso, a suprassunção agora em jogo para Hegel é sobretudo a suprassunção da forma da objetividade intencionada no sentido de uma objetividade meramente epistêmica (pertencente à Consciência como tal); de onde, a objetividade intencionada que a partir de agora será o caso (o da consciência-de-si do Espírito enquanto objeto da consciência deste) ser melhor denominada como atividade intencionada ou teleológica (propriamente finalística), no sentido da objetividade do pensar ou do Conceito que não é senão o resultado de sua própria atividade imanente ${ }^{71}$. O que, em última instância, não se refere apenas à instauração do Saber absoluto em sua imediatidade ou ao simples começo (para nós) da Ciência do Absoluto, mas à própria Idéia absoluta enquanto nesta não está em jogo senão o Espírito que "conhece a Idéia como sua verdade absoluta, como a verdade que é em si e para si; a Idéia infinita na qual conhecer e agir se igualam e que é o Saber absoluto de si mesma" ${ }^{\prime 2}$.Assim, para além de sua figuração espácio-temporal enquanto "Espírito que se sabe", portanto, como "Espírito que se sabe em figura-de-espírito", o Saber absoluto propriamente dito - o conceito que se sabe como conceito ou o Espírito que se sabe como Espírito - só pode instaurar-se definitiva e absolutamente na medida em que o Espírito

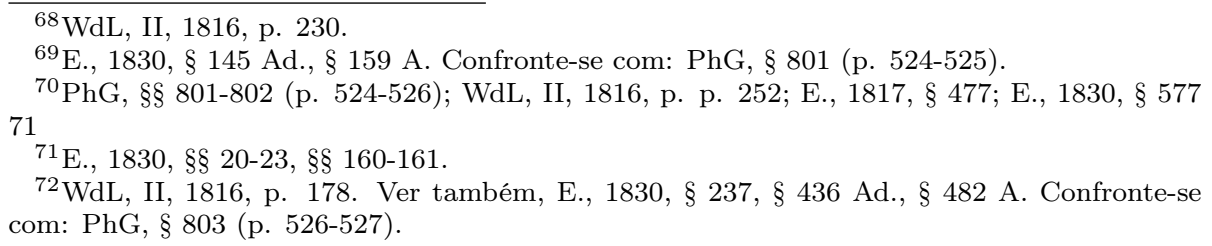


ou o conceito que nele se sabe elimina o tempo e, por conseguinte, suprassume sua figuração espácio-temporal, isto é, sua forma-de-tempo ${ }^{73}$. Isso, de modo a suprassumir a oposição entre o do pensar e o tempo, assumindo-os e mantendoos em sua unidade negativa, deixando a diferença entre ambos a si mesma o tempo sem repouso e pausa -, colapsada dentro de si enquanto a quietude objetiva da extensão ${ }^{74}$.

Desse modo, partindo da constatação de que "o Espírito da religião revelada ainda não ultrapassou sua consciência como tal", incidindo, pois, no representar e na forma da objetividade intencionada, Hegel também constata que o que resta a fazer é só o suprassumir dessa mera forma pertencente à Consciência como tal; contudo, essa suprassunção deve ser levada a cabo de tal modo que só pode ocorrer mediante a extrusão, a um tempo negativa e positiva, da própria consciência-de-si. Ora, para se suprassumir a forma da Consciência como tal há que se perfazerem mais uma vez todos os momentos do Espírito e encontrar nesse perfazer ele mesmo o momento crucial da referida suprassunção; o que, por um lado, implica na determinação dos momentos do Espírito em geral ou imediato $^{75}$ - em cuja forma abstrata ou finita o conteúdo absoluto intencionado pelo Espírito religioso permanece atrelado - enquanto subordinados à representação e à forma da objetividade intencionada e, nesses momentos, em cada caso, as suas determinações fundamentais. Essas permanecem as determinações da Consciência como tal - assim, pertencentes à Consciência imediata, à Percepção e ao Entendimento, pelas quais o Ser-consciente deve saber o objeto intencional como a si mesmo; de onde, até aqui, tal objeto ser o silogismo ou o movimento do universal, através da determinação, para a singularidade, como também o movimento inverso da singularidade como suprassumida, ou da determinação, para o universal ${ }^{76}$. Movimento esse no qual, diz-nos Hegel:

"[...] ainda não aparece o objeto como a essencialidade espiritual [...] e o comportar-se do Ser-consciente para com ele não é a consideração do objeto nessa totalidade; como tal, nem em sua pura forma-de-conceito; mas é, de uma parte, a figura da Consciência em geral, e de outra, um [certo] número de figuras, que nós reunimos, e nas quais a totalidade dos momentos do objeto e do comportamento

\footnotetext{
${ }^{73} \mathrm{PhG}, \S 801$ (p. 524-525).

${ }^{74} \mathrm{PhG}, \S 803$ (p. 527).

${ }^{75}$ Veja-se, PhG, $\S 679$ ss.; $\S 788, \S \S 791-792$ (p. 446 ss., p. 516, p. 518-519): Em geral: Consciência, Autoconsciência, Razão e Espírito. Em particular: (a) no Espírito alienado de si mesmo, a consciência-de si cultivada, a pura Inteligência e o Iluminismo; (b) no Espírito certo de si mesmo, a Autoconsciência moral (moralisches Selbstbewusstsein), a Consciência moral (moralisches Bewusstsein) e, enfim, a boa consciência (Gewissen). Esses, (a) e (b), justamente os momentos em que no - no Espírito - o Juízo infinito e a Contradição absoluta emergem e em que - na boa consciência - esta é suprassumida. Antes desses dois momentos (interiores), porém, há que se lembrar do momento exterior em que, segundo o ponto de vista do conteúdo, na figura da Consciência, o objeto intencional é apreendido; tal é o momento da Razão observadora, no qual o Juízo infinito emerge pela primeira, e com ele a Contradição absoluta (ainda latente), que se desdobra a partir da Razão ativa e se resolve no da individualidade que é a si real em si e para si mesma. Nesse caso, ver, PhG, $\S \S 344-394$ ss., $\S 790$ (p. 231-259 ss., p. p. 517-518).

${ }^{76} \mathrm{PhG}, \S 789$ (p. 517).
} 
do Ser-consciente só se pode mostrar dissolvida nos momentos dessa totalidade". 77

Se o objeto intencional aqui em questão em sua totalidade espiritual é a totalidade de seus momentos, que por sua vez, enquanto totalidade, não é senão o movimento da própria consciência; essa, para apreender o referido objeto em sua totalidade ou, o que é o mesmo, em sua essencialidade espiritual, não só deve relacionar-se com ele segundo a totalidade de suas determinações e apreendê-lo conforme cada uma delas, mas também sabê-lo como a si mesma segundo as determinações da universalidade, da determinidade e da singularidade. Ora, isso não ocorre nos limites da Consciência em geral, pois ela não passa para o lado que pertence a si mesma como tal, limitando-se a ser para si consciente de seu agir apenas como algo exterior, portanto, permanecendo tão somente do lado do objeto tal como ele se torna em verdade para ela, a saber, enquanto um ser imediato ou indiferente; de onde, por um lado, ainda para ela, não haver nenhuma verdadeira totalidade dos momentos do objeto e do comportamento do Ser-consciente para com os mesmos e, por outro, em conseqüência disso, essa totalidade dos momentos do objeto e do comportamento do Ser-consciente se mostrar dissolvida nos mesmos. Todavia, justamente ao afirmar, por exemplo, um tanto quanto ingenuamente, que "o ser do Eu é uma coisa", "a coisa é Eu" ou "o Espírito é uma coisa" e "o Si é uma coisa"78, bem como ao querer com isso determinar o seu ser como uma substância fixa, segundo a forma da proposição em geral, essa Consciência como tal termina por dissolver-se a si mesma - a um tempo como sujeito cognoscente e objeto cognoscível opostos entre si - na medida mesma em que, segundo a diferença de sujeito e predicado imanente ao juízo e à proposição em geral, ela tem que afirmar a identidade de extremos que, como tal, nenhuma relação positiva entre os mesmos pode conter. De onde sua tentativa resultar: (1) na destruição da natureza do juízo e da proposição em geral, (2) na suprassunção da forma do juízo finito e da proposição que o enuncia, e, com isso, (3) na assunção do Juízo infinito como a verdade do juízo negativo e do juízo positivo; portanto, (4) na assunção da Proposição especulativa como sua expressão adequada.

O Juízo infinito é o único dos três princípios motores aqui discutidos que encontra uma melhor elaboração na Phänomenologie des Geistes; o que não significa que Hegel esteja plenamente consciente de seu caráter de princípio motor como tal. Em sua emergência fenomenológica, na medida em que é considerado de modo mais explícito, tal princípio motor se apresenta primeiramente sob o modo de uma constatação da recaída do ponto de vista da Autoconsciência no da Consciência; o que em princípio já ocorrera - para nós (isto é, para o filósofo) - quando do tratamento da figura da Consciência designada como consciência infeliz, essa que "se extrusava de sua independência e lutava para converter seu ser-para-si numa coisa (Ding) ${ }^{79}$. No que tange ao conteúdo, o que está aqui em jogo não é senão a tomada do objeto da Consciência - que neste caso é a

\footnotetext{
${ }^{77} \mathrm{PhG}, \S 789$ (p. 517).

${ }^{78} \mathrm{PhG}, \S \S 341-346, \S \S 790-791$ (p. 228-233, p. 517-518)

${ }^{79} \mathrm{PhG}, \S 344$ (p. 231).
} 
Consciência-de-si - enquanto um ser, uma coisa; no que tange à forma, está em jogo a tentativa de se exprimir um conteúdo em si mesmo infinito, que já é de ordem espiritual ou da esfera do Conceito, utilizando-se da pura e simples forma do juízo finito, essa que se exprime na proposição analítica em geral. Com isso, não obstante a contradição latente na forma positiva imediata do Juízo infinito (aqui enquanto verdade do juízo negativo e do juízo positivo) - na medida em que este afirma uma relação entre termos que não teriam relação alguma ou que são completamente incompatíveis -, opera-se aí uma primeira unidade, a unidade do Eu e da coisa ou do ser, fazendo com que da mera representação subjetiva (limitada à forma do juízo finito) acedamos à Razão, como unidade da Consciência e da Autoconsciência, ou mais propriamente à Categoria, essa que é considerada por Hegel como "a unidade imediata do Ser e do Seu". Do Ser enquanto este é o imediato, o que é em si e cuja consideração incide pura e simplesmente no observar, em suma, o que é determinado tão só enquanto exterior, como um negativo (circunscrito à mera certeza inconsciente resultante do movimento da Razão observadora); do Seu enquanto este é o que exige ser mediatizado, o que é ainda ser-para-si imediato e cuja tematização deverá incidir na efetivação da Autoconsciência racional através de si mesma enquanto Razão ativa $^{80}$. De onde, por um lado, o Juízo infinito constituir-se como um juízo que se suprassume a si mesmo - no caso, enquanto suprassunção da forma do juízo finito e da proposição que o enuncia - e, por outro lado, acrescentar à Categoria a determinação segunda a qual ela mesma é essa oposição que se suprassume ${ }^{81}$, delineando assim o horizonte que será o da Contradição absoluta.

Mas esta suprassunção não pode ser senão a mediação do Ser e do Seu (do Ser-aí e do Si), da Autoconsciência como objeto intencional representado pela Consciência e da Autoconsciência racional ela mesma enquanto efetivando-se a si própria, vale dizer, da oposição e mesmo da contradição que aí se instaura. Situação em que a Autoconsciência não é mais a certeza imediata de ser toda a realidade, mas apresentar-se como uma certeza tal, "que o imediato tem para ela a forma de um suprassumido, de modo que sua objetividade [intencionada epistemicamente] só vale como superfície, cujo interior e essência é a própria Autoconsciência"; de onde essa certeza ter agora de "elevar-se à verdade" para a própria Autoconsciência, isto é, "o que para ela vale como sendo em si, e em sua certeza interior, deve entrar na sua consciência e vir a ser para ela"82. Aqui - enquanto a Consciência se dá uma realidade que é (para além de suas contradições) a Coisa mesma, bem como na medida em que esta se apresenta como essência e que "só é Coisa como agir de todos e de cada um", mostrando-se pois como essência de todas as essências ou como essência espiritual - a Categoria é determinada para a Consciência tal como é na sua verdade universal, como essência em si e para si essente ${ }^{83}$; com o que esta, ao mesmo tempo em que é para si efetiva como Consciência e se representa a si mesma para si, se faz Espírito e, por isso - mais uma vez -, tem de se enfrentar consigo mesma enquanto agora

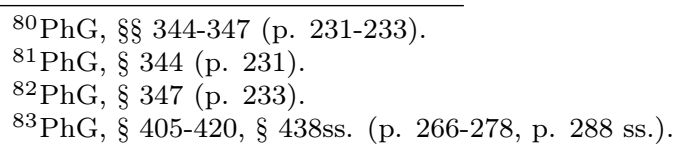


se apresenta - enquanto mundo ético - como o mundo cindido entre o aquém e o além ${ }^{84}$. Mais uma vez - agora para a própria Consciência -, portanto, o Juízo infinito se apresentará, na pura inteligência, na medida mesma em que "se elimina toda a unilateralidade e peculiaridade do ser-para-si originário" 85 isto é, da Autoconsciência universal enquanto o reino do puro pensar que, como tal, para a Autoconsciência singular, permanece necessariamente um além da efetividade desta ${ }^{86}$-, razão pela qual, a partir de agora, o Si se sabe, como puro $\mathrm{Si}$, ser seu objeto intencional; sendo essa igualdade absoluta dos dois lados o elemento da pura inteligência ela mesma. Essa, ao fim e ao cabo, justamente por se saber como a certeza da Razão autoconsciente de ser toda a verdade e não apenas limitar-se a ser tal certeza ${ }^{87}$, da mesma forma que a Autoconsciência racional se efetivara na esfera da Razão ativa, de ora avante estender-se-á enquanto Iluminismo ${ }^{88}$.

Nos casos até aqui considerados, o Juízo infinito se apresenta - respectivamente, na Razão observadora e na pura inteligência - como a dissolução do objeto enquanto algo estranho à Consciência que o tem como oposto a ela e que perante ele se mostra como Consciência-de-si, a saber, o Ser no caso da primeira e o Mundo no da segunda. Em ambos os casos, todavia, instaura-se assim - imediatamente - a oposição e, de modo mais rigoroso, a contradição, em suma: a Contradição absoluta; esta enquanto oposição ou contradição que se suprassume a si mesma e que, como o segundo princípio motor por nós considerado, não é senão o desenvolvimento necessário do Juízo infinito; a saber: (1) como Juízo negativamente infinito (ou, como negação), enquanto destrói a natureza do juízo e da proposição em geral e suprassume a forma do juízo finito e da proposição que o enuncia; (2) como Juízo infinitamente infinito (ou, como negação da negação), enquanto reflexão da singularidade dentro de si mesma e a posição da forma puramente especulativa do julgar e do enunciar ${ }^{89}$. Na Phänomenologie des Geistes, tal contradição (que se suprassume a si mesma) apresenta-se em si na "Individualidade que é a si real em si e para si mesma", para si no "Espírito certo de si mesmo" (ou, na Moralidade) [mas para si unicamente enquanto em sua imediatez], em si e para si na "Religião revelada" [nesta última, contudo, em si e para si tão somente para nós ou em si]. De onde, por um lado, a reconciliação em jogo no Espírito certo de si mesmo limitar-se à forma da Consciência-de-si e a em jogo na Religião revelada ao Espírito religioso (ambas, em última instância, incidindo na forma da Consciência como tal); por outro, todo esse movimento reapresentar-se no âmbito da instauração do Saber absoluto. Isso, na medida em que este, ao suprassumir as duas formas opostas de reconciliação (que terminam por incidir na Consciência como tal): de um lado, leva a termo o saber de si do Espírito enquanto em si e para si, já presente em si na reconciliação operada na Religião revelada; de outro, a reflexão dentro-

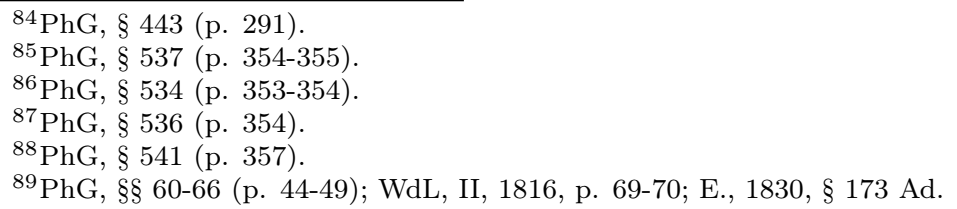


de-si (o lado que contém a si mesmo e ao seu contrário, que não é só em si, mas também para si) já presente no Espírito certo de si mesmo, mais propriamente na Bela Alma, enquanto auto-intuição do divino.

Desse modo, a reconciliação em jogo no Saber absoluto apresenta-se ela mesma como uma reconciliação absoluta. Há que se reconciliar agora justamente o Espírito em seu conceito - que se mostrara como auto-intuição do divino, "o Espírito certo de si mesmo que permanece firme dentro de seu conceito"90 - e a sua realização (Realisierung), que se apresentara primeiramente na Religião em geral e na Religião revelada em particular. De um lado, a reconciliação do Espírito consigo mesmo em seu ser-aí imediato, efetuada na esfera da Consciência como tal e sob a forma do ser-para-si ou da Consciência-de-si de uma maneira desenvolvida e diferenciada, contendo a si mesmo e a seu outro - enquanto "este Si singular que é imediatamente saber puro ou universal"; de outro, a reconciliação do Espírito consigo mesmo em seu ser-aí mediatizado ou em sua própria efetivação, na esfera do Espírito religioso e sob a forma do serem-si ou da Consciência como tal - dando ao seu objeto intencional, segundo seu conteúdo absoluto, a figura de consciência-de-si efetiva - enquanto o Espírito que é em si e para $\mathrm{si}^{91}$. Trata-se, pois, em ambos os casos, assim como na reconciliação absoluta agora em jogo, de suprassumir a própria Consciência como tal na qual, em última instância, as duas primeiras formas de reconciliação ainda se circunscrevem, mas permanecem opostas entre si como o lado da forma versus o do conteúdo; de fato, para que a reconciliação absoluta possa realizarse, é preciso que a Consciência como tal ela mesma suprassuma-se a si própria enquanto tal oposição. Entretanto, como por seus próprios meios a Consciência como tal não é capaz de dar esses passos e, assim, suprassumir-se a si mesma, (a) em um primeiro momento - e eis aí o que Hegel chamou a significação negativa da extrusão da consciência-de-si - ela subordina a si a consciência-de-si que mediante o Juízo infinito se extrusa, portanto, fazendo com que tal Juízo infinito, que enuncia essa consciência-de-si, enquanto ela é o próprio Para-si, ainda que imediato, e justamente por ainda ela ser mera consciência-de-si imediata, se apresente como algo carente de conteúdo ou espírito, ou ainda como a própria carência-de-espírito ou de conteúdo. Todavia, (b) em um segundo momento, por seu turno o que Hegel chamou a significação positiva da extrusão da consciência-de-si, quanto ao seu conceito, esse Juízo infinito é de fato o mais rico-de-espírito, sendo justamente o seu interior que é expresso nos dois outros momentos seguintes: (1) a suprassunção da coisa e sua referência ao Eu segundo a imediatez do ser e segundo a determinidade [isto é, do ser sendo aí enquanto desprendido do $\mathrm{Si}$ ] e (2) a assunção da essência ou do interior como o próprio $\mathrm{Si}$, do qual se desprende o ser-aí que, não obstante, é por ele recuperado dentro de si mesmo ${ }^{92}$.

Esses dois momentos que exprimem o interior do Juízo infinito, a saber: o momento do Ser-aí e o momento do Si, são, segundo Hegel, "os momentos dos

${ }^{90} \mathrm{PhG}, \S 671, \S 795$ (p. 442, p. 520 )

${ }^{91} \mathrm{PhG}, \S \S 793-794$ (p. 519-520).

${ }^{92} \mathrm{PhG}, \S 788, \S 792$ (p. 516, p. 518). 
quais se compõe a reconciliação do Espírito com sua peculiar consciência"93; como tais, em sua unidade espiritual, esses momentos não são senão os termos relacionados que entram em jogo na Proposição especulativa, a qual, contudo, não poderá se limitar nem à forma do em si, própria do Espírito religioso, nem à forma do para si, própria, ainda, da Consciência como tal. Formas essas que, em razão de sua oposição no seio mesmo da reconciliação, fazem com que o Juízo infinito ceda lugar à Contradição absoluta, na qual os dois lados, a saber: o do Espírito religioso e o da Consciência como tal, se diferenciam e incidem um fora do outro; sendo justamente em contraposição à unificação da Consciência como tal (para si, mas destituída de conteúdo, enquanto mera consciência-desi abstrata ou imediata), que a religião também dá a seu objeto a figura de consciência-de-si efetiva, isto é, como o que é em si ou segundo seu conteúdo absoluto $^{94}$. Neste sentido, aquela afirmação com a qual Hegel inicia o capítulo sobre o Saber absoluto se nos mostra como que enunciando a Contradição absoluta ela mesma; pois, se "o Espírito da religião revelada ainda não ultrapassou seu Ser-consciente como tal, ou, o que é o mesmo, [se] sua Consciência-de-si efetiva não é o objeto de sua Consciência", isso só pode querer dizer que, agora, não é senão o Espírito da religião que, ao encerrar-se na imediatez do Em-si, e precisamente por haver realizado uma primeira unificação, ainda que em-si, dos dois lados da reconciliação, termina por impedir à consciência-de-si efetiva em si do Espírito tornar-se ela mesma para si. O que, enfim, se funda no fato da efetividade imediata dessa consciência-de-si efetiva, que é saber puro ou imediato do Espírito certo de si, tomar esse saber de si do Espírito tão somente como elemento do seu ser-aí, de onde sua recaída na oposição vazia entre o saber desse Si puramente singular e saber como universal ${ }^{95}$.

Ora, ao não assumir em si, enquanto saber, o próprio saber como universal, tal como esse é para si enquanto totalidade de seus momentos singulares, o saber do si singular se rebaixa à simples postulação da universalidade ou ao seu caráter meramente em si ou abstrato. Por isso, a unificação levada a cabo pela religião em torno das formas de reconciliação não pode se dar segundo sua forma autêntica - de onde se poder afirmar que, segundo a forma, a religião permanece pura e simplesmente no momento do Juízo negativamente infinito e, com isso, faz com que a Contradição absoluta se apresente em seu caráter absolutamente absoluto; pois, diz-nos Hegel, "o lado religioso é o lado do Em-si, que se contrapõe ao movimento da consciência-de-si" "96. Essa forma autêntica, por conseguinte, só pode ser o lado da Reflexão-dentro-si, pois, ainda segundo Hegel, "esse contém a si mesmo e ao seu contrário, e não só em si, ou de uma maneira geral, mas para si ou de uma maneira desenvolvida e diferenciada" 97 ; de onde, aqui, e só aqui, poder-se afirmar a plena unidade espiritual do ser-aí e do si que constitui a força da reconciliação da consciência e da consciência-de-si efetiva do Espírito, mas isso só quer dizer que aqui o Espírito consegue manter

${ }^{93} \mathrm{PhG}, \S \S 632-671, \S 793$ (p. 415-442, p. 519).

${ }^{94} \mathrm{PhG}, \S 794$ (p. 519-520).

${ }^{95} \mathrm{PhG}, \S 794$ (p. 519-520).

${ }^{96} \mathrm{PhG}, \S 795$ (p. 520).

${ }^{97} \mathrm{PhG}, \S 795$ (p. 520). 
firme a contradição e nela manter-se firme a si mesmo, faltando portanto ainda uma última unificação e, de fato, a mais importante, aquela que irá realizar em sua plenitude a exigência da consciência-de-si do Espírito tornar-se objeto de sua consciência, isto é, a unidade simples do conceito e a sua enunciação propriamente especulativa. Pois bem, ainda na forma do ser-outro para a consciência, isto é, na forma da representação, o conceito ganhou, enquanto conteúdo, na religião, o conteúdo absoluto; já na figura do Espírito operante, cuja forma é o próprio si, o conceito abandona sua essência eterna e "é-aî" ou opera, com o que, em sua pureza ou negatividade, ele se cinde ou emerge, mas tendo dentro dele ou no puro saber mesmo o elemento de sua efetividade ou ser. Esse saber puro, diz-nos Hegel, "é a imediatez simples, que é tanto ser e ser-aí quanto essência", no primeiro caso, é o pensar negativo; no segundo, é o pensar positivo mesmo ${ }^{98}$; assim, em suprassumindo a si mesmo, tanto em sua imediatez quanto em sua mediação, vindo a ser essência e Si, o Espírito eleva seu ser-aí ao pensamento e por isso à oposição absoluta, e desta, por ela e nela mesma retorna, surgindo como pura universalidade do saber, ou ainda, como a pura Autoconsciência que se desenvolve a si mesma ou que é unidade simples do saber ${ }^{99}$. De onde, ao fim e ao cabo, aquela unificação que ainda faltava, ou a unidade simples do conceito, não se apresentar senão "o saber do agir do Si dentro de si como saber de toda a essencialidade e de todo o ser-aî"100.

Com isso, passamos ao terceiro nível estrutural; a saber: (3) ao fato da Consciência-de-si do Espírito tornar-se objeto intencional de sua Consciência, do Saber absoluto que se põe a si mesmo, do estabelecimento do conceito da Ciência pura. Em resumo, ao se pôr o problema da consciência-de-si do Espírito tornar-se objeto de sua consciência, Hegel se põe a explicitar o modo da reconciliação entre a Consciência e a Autoconsciência, as quais, contudo, uma vez reconciliadas, caem na oposição entre os próprios modos de reconciliação, os quais - por seu turno - , justamente por isso, devem ser reconciliados; um, o Espírito religioso: que se limita à forma do em si, outro: a consciência como tal, limitando-se à forma do para si. Assim, para que a própria reconciliação se reconcilie consigo mesma, faz-se necessário três momentos: (1) a Religião, enquanto retorno da representação à consciência-de-si, (2) a Reflexão dentro-de-si, como o momento que contém a si mesmo e ao seu contrário e (3) a Unidade simples do conceito ou "o saber do agir do Si dentro de si como saber de toda a essencialidade e de todo o ser-aî"101. Contudo, se no momento da Religião a unificação na qual o Espírito se sabe em si e para si ocorre apenas em si ou para nós, o momento fundamental de tal unificação só poderá ser o da Reflexãodentro-de-si - devido a que este contém a si mesmo e ao seu contrário, sendo em si e para si, desenvolvido e diferenciado - no qual se fazem presentes tanto o conteúdo absoluto quanto o outro lado do Espírito consciente de si (a forma absoluta ou a auto-intuição do Absoluto); os quais, assim, se mostram em sua integralidade. De onde, por conseguinte, a instauração da unificação que ainda

\footnotetext{
${ }^{98} \mathrm{PhG}, \S 796($ p. 520).

${ }^{99} \mathrm{PhG}, \S 797($ p. 522); WdL, I, 1, 1832, 33.

${ }^{100} \mathrm{PhG}, \S 797$ (p. 522)

${ }^{101} \mathrm{PhG}, \S 795, \S 797$ (p. 520, p. 522).
} 
faltava, a unidade simples do Conceito, que aqui se mostra como resultado do processo total.

Ora, no que tange à sua constituição propriamente especulativa, esses três momentos da reconciliação que se reconcilia consigo mesma e que articulam as formas de unificação que nela têm lugar não são senão desdobramentos do Juízo infinito cujos momentos interiores são inicialmente os momentos dos quais se compõe a reconciliação do Espírito com sua peculiar consciência [e que como tal foi desenvolvida nos §§ finais da seção (BB) O Espírito]. Momentos esses, o ser-aí e o si, que se mostrarão como o cerne do que está em jogo nas formas de unificação do Espírito religioso ou segundo o conteúdo absoluto e da consciência-de-si ou segundo a carência-de-conteúdo (justamente pelo fato da unidade simples do Conceito, ou a unificação que ainda faltava, já estar presente no lado da consciência-de-si, ainda que sob a forma de uma figura da consciência ou em sua imediatez): de um lado, o ser-aí que na primeira forma de reconciliação se apresenta como o próprio conteúdo absoluto em sua objetividade intencionada pela consciência como tal; de outro, o si que na segunda forma de reconciliação se apresenta carente-de-conteúdo devido a circunscrever-se ao "puro saber sobre o ser-dentro-de-si" 102 . De onde, em seu desenvolvimento, tais momentos consistirem: (1) na suprassunção da coisa e sua referência ao Eu segundo a imediatez do ser e segundo a determinidade [o ser sendo aí enquanto desprendido do $\mathrm{Si}$ ] e (2) na assunção da essência ou do interior como o próprio $\mathrm{Si}$, do qual se desprende o ser-aí que, não obstante, é por ele recuperado dentro de si mesmo $^{103}$.

Por isso, enfim, se esses momentos são realmente os momentos dos quais se compõe a reconciliação absoluta na qual o Espírito vem a ser em si e para si, ela mesma terá que ser o próprio Juízo infinito agora restabelecido em sua forma puramente especulativa. Neste sentido, os momentos lógico-efetivos deste - (1) o Juízo positivamente infinito [enquanto verdade do juízo negativo e do juízo positivo], (2) o Juízo negativamente infinito [enquanto destrói a natureza do juízo e da proposição em geral e suprassume a forma do juízo finito e da proposição que o enuncia] e (3) o Juízo infinitamente infinito [enquanto negação da negação ou posição da forma puramente especulativa do julgar e do enunciar] - não poderão se articular senão enquanto se desenvolvem nos dois outros princípios motores do Especulativo puro, a saber: (1) na posição e suprassunção da Contradição absoluta enquanto a (2) enuncia de modo adequado na chamada Proposição especulativa. Mostremos, pois, a título de conclusão, em que medida os referidos princípios motores autoconstituem e autoregulam a própria instauração do Saber absoluto.

\section{Considerações finais}

Apesar do estado de inacabamento do capítulo final da Phänomenologie des Geistes e, em especial, do caráter meramente pressuposto dos princípios motores

\footnotetext{
${ }^{102} \mathrm{PhG}, \S 795$ (p. 520).

${ }^{103} \mathrm{PhG}$, § 795 (p. 520).
} 
do Especulativo puro na instauração do Saber absoluto aí em jogo, pode-se dizer que, pelo menos para o Juízo infinito, a estrutura imanente do Saber absoluto, ou do modo como a consciência-de-si do Espírito se torna objeto de sua consciência, foi aqui plenamente determinada. Contudo, na medida em que é a partir da estrutura mesma do Juízo infinito que a Contradição absoluta emerge - sobretudo em razão de suprassumir-se a si mesma - e a Proposição especulativa se revela (como enunciação do próprio Juízo infinito), de modo que os últimos princípios motores podem ser reduzidos ao primeiro e só a partir deste é que são plenamente desenvolvidos, podem-se considerar como determinados - ainda que apenas em suas linhas gerais - também os princípios ulteriores. De onde, em um primeiro momento, (a) o estabelecimento do Saber absoluto enquanto a última figura do Espírito e, em um segundo momento, (b) sua instauração propriamente dita como tal para além de sua figuração espácio-temporal.

Enquanto o estabelecimento do Saber absoluto como a última figura do Espírito pode ser considerado no âmbito do Juízo infinito em sua imediatidade do Juízo positivamente infinito enquanto verdade do juízo negativo e do juízo positivo, aqui, do Espírito certo de si mesmo e do Espírito religioso - a instauração propriamente dita do Saber absoluto como tal, para além de sua figuração espácio-temporal, deve ser compreendida no plano do Juízo negativamente infinito - na medida em que este destrói a natureza do juízo e da proposição em geral e suprassume a forma do juízo finito e da proposição que o enuncia - justamente em função da eliminação do tempo aí em questão ${ }^{104}$. Entretanto, como esta eliminação consiste tão somente em deixar a si mesma a diferença do pensar e do tempo - deixar a si mesmo o tempo sem repouso e pausa -, colapsando tal diferença dentro de si mesma, a referida eliminação terá que ser ela mesma negada ou suprassumida - como a compreensão pelo Espírito de seu conceito na suprassunção pelo conceito, enquanto este se compreende a si mesmo, de sua forma-de-tempo. De onde o Juízo negativamente infinito no qual a Contradição absoluta se apresenta - junto com o Juízo positivamente infinito - concluir-se no Juízo infinitamente infinito; este que, enquanto negação da negação ou posição da forma puramente especulativa do julgar e do enunciar, exprime a unidade mesma do pensar e do tempo enquanto a pura igualdade consigo mesma, o Eu. Aqui, do Eu que não é apenas o Si, mas a igualdade do Si consigo mesmo, a igualdade que é a perfeita e imediata unidade consigo mesma, o sujeito que é igualmente substância ${ }^{105}$.

Assim, ao fim e ao cabo, o Espírito não só conclui o movimento de seu configurar-se na esfera fenomenológica, suprassumindo a diferença não-superada da consciência e ganhando o puro elemento do seu ser-aí - o conceito - mas suprassume também a própria Fenomenologia do Espírito enquanto esfera de tal diferença não-superada e de sua suprassunção ${ }^{106}$. Caso em que o Espírito - como o movimento do $\mathrm{Si}$ - se extrusa de si mesmo e se submerge em sua substância, tanto saindo dessa substância como sujeito e se adentrando em si, convertendo-a em objeto intencional e conteúdo, quanto suprassumindo essa

\footnotetext{
${ }^{104} \mathrm{PhG}, \S 801$ (p. 524).

${ }^{105} \mathrm{PhG}, \S 803$ (p. 526-527).

${ }^{106} \mathrm{PhG}, \S 805$ (p. 528-529).
} 
diferença entre a objetividade epistêmica e o conteúdo; com isso, libertando-se de sua manifestação na consciência ${ }^{107}$. De ora avante, o Saber deve afirmar-se como o subsistir do ser-aí para si que é o conceito posto na determinidade e que é igualmente seu movimento, nele mesmo, de ir mais fundo dentro da substância simples, que só é sujeito enquanto esta negatividade e movimento ${ }^{108}$. O que, infelizmente, não pode ser o caso na esfera fenomenológica, onde ele se restringe a submergir na noite de sua consciência-de-si e nela conservar o seu ser-aí que aí desvaneceu, suprassumido que foi para dar origem - como ser-aí suprassumido - a um novo ser-aí, um novo mundo e uma nova figura-de-espírito ${ }^{109}$.

\section{Referências}

[1] HEGEL, G. W. F., Leçons sur la logique (1831), présentation de Jean-Marie Lardic, traduction et notes de jean-Michel Buée et David Wittmann, Paris: Vrin, 2007.

[2] - Fenomenologia do Espírito.Trad. Paulo Meneses - 2. Ed. - São Paulo: Loyola, 2003.

[3] — Enciclopédia das Ciências Filosóficas em Compêndio (1830), trad. Paulo Meneses e Pe. José Machado, São Paulo: Loyola, 1995.

[4] — Vorlesunguen über Logik und Metaphysik (Heidelberg 1817). Mitgeschrieben von F. A. Good. Herausgegeben von Karen Gloy, unter Mitarbeit von Manuel Bachmann, Reinhard Heckmann und Rainer Lambrecht. Hamburg: Felix Meiner, 1992.

[5] — Phänomenologie des Geistes (1807), neu hrsg. von Hans-Friedrich Wessels u. Heirinch Clairmont. Mit e. Einleitung von Wolfgang Bonsiepen. Hamburg: Meiner, 1988.

[6] Wissenschaft der Logik. Erster Teil: Die objektive Logik. Erster Band: Die Lehre vom Sein (1832), herausgegeben von Friedrich Hogemann und Walter Jaeschke. Hamburg: Felix Meiner, 1985 [GW 21].

[7] — Wissenschaft der Logik. Zweiter Band: Die subjektive Logik (1816), herausgegeben von Friedrich Hogemann und Walter Jaeschke. Hamburg: Felix Meiner, 1981 [GW 12]. HEGEL, G. W. F., Wissenschaft der Logik. Erster Band: Die objektive Logik. (1812/1813), herausgegeben von Friedrich Hogemann und Walter Jaeschke. Hamburg: Felix Meiner, 1978 [GW $11]$.

[8] — Briefe von und an Hegel, Band I: 1785-1812, Hg. von Johannes Hoffmeister, Berlin: Akademie Verlag, 1970.

\footnotetext{
${ }^{107} \mathrm{PhG}, \S \S 804-805$ (p. 527-529); WdL, I, 1, 1832, p. 33.

${ }^{108} \mathrm{PhG}, \S 804$ (p. 527).

${ }^{109} \mathrm{PhG}, \S 808$ (p. 530).
} 
[9] Grundlinien der Philosophie des Rechts oder Naturrechts und Staatswissenschaft im Grundrisse, mit Hegels eigenhändigen Notizen und den mündlichen Zusätzen. Auf der Grundlage der Werke von 1832-1845 neu edierte Ausgabe. Redaktion: Eva Moldenhauer und Karl Markus Michel. Frankfurt am Main: Suhrkamp, 1970 [TWA 7].

[10] _ Jenaer Schriften (1801-1807). Auf der Grundlage der Werke von 18321845 neu edierte Ausgabe. Redaktion Eva Moldenhauer und Karl Markus Michel. Frankfurt am Main: Suhrkamp, 1970 [TWA 2].

[11] _ Encyklopädie der philosophischen Wissenschaften im Grundrisse und andere Schriften aus der Heidelberg Zeit, neue herausgegeben von Hermann Glockner, Heidelberg: Frommanns Verlag, 1956 [SW 6].

[12] PROCLUS, Théologie platonicienne, texte établi et traduit par H. D. Saffrey et L. G. Westerink, Paris: Belles Lettres, 2003. (v. II; v. III).

[13] SILVA, M. M.; WUICK, R. O universal ativo e suas determinações fundamentais: uma introdução à leitura especulativa dos $\S \S 20-23$ da Enciclopédia das ciências filosóficas em compêndio (1830) de Hegel. In: Revista Eletrônica Estudos Hegelianos, Recife/PE, v. 04, n. 06, (2007): URL = $<$ http://www.hegelbrasil.org/rev06b.htm $>$.

[14] — O problema da Fundação especulativa do Especulativo puro no Sistema de Hegel e a determinação especulativa dos Princípios motores da Lógica especulativa, in: Revista Eletrônica Estudos Hegelianos, Recife/PE, v. 02, n. 03, (2005): URL $=<$ http://www.hegelbrasil.org/rev03e.htm $>$. 